\title{
Comparison of earthquake source characteristics in the Kachchh Rift Basin and Saurashtra horst, Deccan Volcanic Province, western India
}

\author{
B Sairam ${ }^{1, *} \oplus$, A P Singh ${ }^{1}$ and M Ravi $\operatorname{Kumar}^{1,2}$ \\ ${ }^{1}$ Institute of Seismological Research, Raisan, Gandhinagar 382007, India. \\ ${ }^{2}$ CSIR-National Geophysical Research Institute, Hyderabad 500 007, India. \\ ${ }^{*}$ Corresponding author.e-mail: sairam.b78@gmail.com
}

MS received 2 March 2017; revised 3 October 2017; accepted 8 October 2017; published online 23 May 2018

Seismic source parameters of small to moderate sized intraplate earthquakes that occurred during 20022009 in the tectonic blocks of Kachchh Rift Basin (KRB) and the Saurashtra Horst (SH), in the stable continental region of western peninsular India, are studied through spectral analysis of shear waves. The data of aftershock sequence of the 2001 Bhuj earthquake $\left(M_{w} 7.7\right)$ in the KRB and the 2007 Talala earthquake $\left(M_{w}\right.$ 5.0) in the $\mathrm{SH}$ are used for this study. In the $\mathrm{SH}$, the seismic moment $\left(M_{o}\right)$, corner frequency $\left(f_{c}\right)$, stress drop $(\Delta \sigma)$ and source radius $(r)$ vary from $7.8 \times 10^{11}$ to $4.0 \times 10^{16} \mathrm{~N}-\mathrm{m}, 1.0^{-}$ $8.9 \mathrm{~Hz}, 4.8-10.2 \mathrm{MPa}$ and $195-1480 \mathrm{~m}$, respectively. While in the KRB, these parameters vary from $M_{o} \sim 1.24 \times 10^{11}$ to $4.1 \times 10^{16} \mathrm{~N}-\mathrm{m}, f_{c} \sim 1.6$ to $13.1 \mathrm{~Hz}, \Delta \sigma \sim 0.06$ to $16.62 \mathrm{MPa}$ and $r \sim 100$ to $840 \mathrm{~m}$. The kappa $(K)$ value in the KRB $(0.025-0.03)$ is slightly larger than that in the SH region (0.02), probably due to thick sedimentary layers. The estimated stress drops of earthquakes in the KRB are relatively higher than those in SH, due to large crustal stress concentration associated with mafic/ultramafic rocks at the hypocentral depths. The results also suggest that the stress drop value of intraplate earthquakes is larger than the interplate earthquakes. In addition, it is observed that the strike-slip events in the $\mathrm{SH}$ have lower stress drops, compared to the thrust and strike-slip events.

Keywords. Stress drop; seismic moment; focal mechanisms; seismotectonics.

\section{Introduction}

The Kachchh Rift Basin (KRB) and Saurashtra Horst $(\mathrm{SH})$ in the northwestern Deccan Volcanic Province (NWDVP) of India, experienced several moderate to major intraplate earthquakes over a period of less than 200 years (Rao and Rao 1984; Rajendran and Rajendran 1999, 2001; Gupta et al. 2001; Singh et al. 2015; Singh and Mishra 2015). The devastating 2001 Bhuj earthquake $\left(M_{w} 7.7\right)$ in the KRB and the earthquakes of $M_{w} 5.0$ and 5.1 in the $\mathrm{SH}$ that occurred during the years 2007 and 2011 (Yadav et al. 2011; Singh et al. 2013; Singh and Mishra 2015) renewed the interest of researchers in understanding the seismotectonic settings of these two seismically active regions. In fact, the KRB has been recognized as one of the most active intraplate seismic regions of the world (Talwani and Gangopadhyay 2001; Kayal et al. 2002; Rastogi et al. 2014; Singh et al. 2015). The region has been classified as the highly vulnerable seismic zone $\mathrm{V}$, on the seismic zoning map of India (BIS 2002). On the other hand, the Saurashtra region is classified as a seismically active zone III. 
The 2001 Bhuj earthquake has been considered as the largest intraplate earthquake that occurred in the era of modern seismology. Several researchers suggested that the Bhuj earthquake was generated due to fluid filled fractures rock matrices at the depth of 20-25 km (e.g., Kayal et al. 2002; Negishi et al. 2002; Mishra and Zhao 2003; Mandal et al. 2004b; Mandal and Pujol 2006; Sastry et al. 2008; Naganjaneyulu et al. 2010; Singh et al. 2012, 2017). Aftershocks of this earthquake having magnitudes up to $M_{w} 5$ have continued for over a decade. Also, several triggered earthquakes of $M_{w} \geq 5.6$ occurred along different faults in Kachchh, the distant one being about $75 \mathrm{~km}$ from the mainshock epicenter (Mandal et al. 2007). On the other hand, the $\mathrm{SH}$, which is a different tectonic province, has also been experiencing intermittent tremor activity at some places, during the last two centuries (Srivastava and Rao 1997; Singh et al. 2017).

It has now been established that the intracratonic seismicity in the KRB is associated with the $\mathrm{E}-\mathrm{W}$ trending failed rift basin (Biswas 2005) that is underlain by a Precambrian basement. The rift basin is bounded by two major faults, the E-W trending Nagar Parkar Fault (NPF) in the north and the ENE-WSW trending North Kathiawar Fault (NKF) in the south (Biswas 2005). This basin is experiencing inversion tectonics under a compressional stress regime due to the northward movement of the Indian plate. The seismicity within the rift basin is fault controlled. On the other hand, the seismotectonics of the $\mathrm{SH}$ is hitherto less studied. In contrast to Kachchh, the seismicity in Saurashtra is confined within a horst structure, which is bound by faults on all sides. The southern fringe is bound by the extended Narmada-Son Fault (NSF), the northern boundary by the NKF, the western boundary by the WNW-ESE trending West Coast Fault (WCF) and the eastern one by the extension of WCF. The focal depths of the 2007 and 2011 Talala earthquakes are shallower than $20 \mathrm{~km}$ (Singh et al. 2015). Additionally, the SH is associated with episodic swarm activity with reports of sounds at several places such as Lalpur, Kalawad, Chotila, Botad, Chobari, Surendranagar and Ankolvadi in the NWDVP, Gujarat (Chopra et al. 2008a; Singh et al. 2017). The KRB and the $\mathrm{SH}$, that are adjacent to each other exhibit remarkably distinct tectonic characteristics. In this context, it is interesting to compare the source parameters (SPs) of small to moderate earthquakes recorded by a very dense network of broadband seismic stations.

Aki (1967) and Brune (1970) proposed a procedure to quantify the size of an earthquake. They modeled the average displacement spectrum of an earthquake with three independent parameters, the low-frequency spectral flat level $\left(\Omega_{o}\right)$, highfrequency spectral decay (typically $\omega^{-2}$ ) and corner frequency $\left(f_{c}\right)$. Although, several methods are used to study the earthquake source parameters, timedomain modeling of waveform amplitudes and source time functions (Langston and Helmberger 1975; Cohn et al. 1982), analysis of the spectra of P, S or surface waves (Aki 1967; Brune 1970; Hanks and Kanamori 1979; Fletcher et al. 1984) are commonly employed. The spectral parameters $\left(\Omega_{o}\right.$ and $f_{c}$ ) may be used to estimate other SPs like seismic moment $\left(M_{o}\right)$, stress drop $(\Delta \sigma)$ and source radius $(r)$. Corner frequency $\left(f_{c}\right)$ is related to the dimension of the fault and $\Omega_{o}$ is related to $M_{o}$. It is well known that $\Delta \sigma$ represents difference between the initial and final stress present on the surface of a shear dislocation is a significant source parameter associated with $M_{o}$ (Aki 1967; Brune 1970).

Earthquake SPs are important to understand the seismotectonics of a region (Abercrombie and Leary 1993; Chung 1993; Chung and Gao 1995; Akinci et al. 2013), assess the seismic hazard associated with a seismically active region (e.g., Lee et al. 2003; Kumar et al. 2015) and simulate the ground motion for a given magnitude (Boore 2003), where actual seismograms are not available. Earlier studies based on SPs are mainly restricted to the moderate to large size earthquakes (e.g., Negishi et al. 2002; Bodin and Horton 2004; Singh et al. 2004) and small earthquakes in the 2001 Bhuj source zones (e.g., Mandal and Johnston 2006; Mandal and Dutta 2011; Saha et al. 2012; Rapolu and Mandal 2014; Kumar et al. 2014, 2015; Trivedi and Parvez 2015; Nagamani and Mandal 2017). The results revealed that the mainshock is associated with a higher stress drop than those along the plate boundaries. The upper bound value of stress drop of earthquakes in the study regions is roughly equal to the Bhuj mainshock (table 1). However, the SPs of small earthquakes vary significantly, in all the studies (table 2). The variation of parameters could be due to the different size of earthquakes and the limited events recorded during restricted time-periods. Nagamani and Mandal (2017) argued that the static stress drop values are higher than the apparent stress drop values. Based on waveform modeling, Mandal and 
Table 1. Earthquake source parameters of the 2001 Bhuj mainshock ( $M_{w}$ 7.7).

\begin{tabular}{llccl}
\hline $\begin{array}{l}\text { Stress drop } \\
(\Delta \sigma) \mathrm{MPa}\end{array}$ & $\begin{array}{c}\text { Seismic moment } \\
\left(M_{o}\right) \mathrm{N}-\mathrm{m}\end{array}$ & $\begin{array}{c}\text { Source radius } \\
(r)\end{array}$ & $\begin{array}{c}\text { Rupture area } \\
\left(\mathrm{km}^{2}\right)\end{array}$ & \multicolumn{1}{c}{ References } \\
\hline 20 & - & - & - & Antolik and Dreger (2003) \\
$12.6-24.6$ & $4.5 \times 10^{20}$ & $20-25 \mathrm{~km}$ & - & Negishi et al. (2002) \\
$16 \pm 2$ & $(2.3-3.6) \times 10^{20}$ & - & $1300 \mathrm{~km}^{2}$ & Bodin and Horton (2004) \\
20 & $3.4 \times 10^{20}$ & - & - & Singh et al. (2004) \\
\hline
\end{tabular}

Table 2. Estimated earthquake source parameters in the Kachchh Rift Basin by earlier studies.

\begin{tabular}{llllll}
\hline$M_{w}$ & $\begin{array}{c}\text { Stress drop, } \\
\Delta \sigma(\mathrm{MPa})\end{array}$ & $\begin{array}{c}\text { Seismic moment, } \\
M_{o}(\mathrm{~N}-\mathrm{m})\end{array}$ & $\begin{array}{c}\text { Source } \\
\text { radius, } r(\mathrm{~m})\end{array}$ & $\begin{array}{c}\text { Corner frequency } \\
(\mathrm{Hz})\end{array}$ & \multicolumn{1}{c}{ References } \\
\hline $2.16-5.74$ & $0.63-20.7$ & $1.95 \times 10^{12}-4.5 \times 10^{17}$ & $239-2835$ & $0.9-11.0$ & Mandal and Johnston (2006) \\
$2.93-5.32$ & $0.11-7.44$ & $3.1 \times 10^{13}-2.0 \times 10^{17}$ & $226-889$ & $1.7-6.75$ & Mandal and Dutta (2011) \\
$1.7-5.6$ & $0.13-26.7$ & $3.55 \times 10^{11}-2.84 \times 10^{17}$ & $107-1515$ & $1.3-11.83$ & Rapolu and Mandal (2014) \\
$3.3-4.9$ & $3.2-13.6$ & $1.02 \times 10^{14}-3.4 \times 10^{16}$ & $233-857$ & $2.11-6.51$ & Kumar et al. (2014) \\
$2.05-5.52$ & $0.1-14.4$ & $1.5 \times 10^{12}-2.4 \times 10^{17}$ & $139.1-933.9$ & $1.4-9.3$ & Kumar et al. $(2015)$ \\
$3.5-5.7$ & $6.84-29.98$ & $2.0 \times 10^{14}-6.3 \times 10^{17}$ & $168-2100$ & $0.62-8.18$ & Trivedi and Parvez (2015) \\
\hline
\end{tabular}

Johnston (2006) found that the values of $M_{o}$ show scatter above $10^{14.5} \mathrm{~N}-\mathrm{m}$ for the Bhuj aftershocks. Kumar et al. (2014) studied the SPs of 34 earthquakes of $M_{w} 3.3-4.9$ in the KRB, recorded by a network of Strong Motion Accelerographs (SMA). Their estimates of $\Delta \sigma$ values lie in the range 30 120 bars. Usually, the stress drop values for higher magnitude events are scattered in nature and more systematic for smaller events (Mandal and Johnston 2006). In the KRB, earthquakes are associated with all types of focal mechanisms; reverse faulting with a minor strike-slip component being the dominant one (Mandal 2008; Singh et al. 2016). In the $\mathrm{SH}$, most of the earthquakes have strike-slip mechanisms (Singh et al. 2015).

In the present paper, our major goal is to understand the seismotectonics of the two geologically distinct contiguous regions. Improved data quality due to the dense seismological network has provided an opportunity to estimate the SPs and fault plane solutions and to gain new insights on the seismotectonics and earthquake generating processes, which we highlight in this paper.

\section{Geology and seismotectonics}

Gujarat is a western state of India, which covers an area of approximately $200,000 \mathrm{~km}^{2}(500 \times$ $400 \mathrm{~km}$ ) between $20.0^{\circ}-24.5^{\circ} \mathrm{N}$ latitude and $68.0^{\circ}-$ $74.5^{\circ} \mathrm{E}$ longitude. The Gujarat state consists of three distinct zones: Saurashtra, Mainland Gujarat and Kachchh (figure 1a). The structural setting of Gujarat is controlled by two major Precambrian orogenic trends, i.e., the NE-SW Aravalli and the ENE-WSW Satpura trend. Reactivated movements along these trends gave rise to three important rift basins: (1) the Kachchh basin, (2) the Cambay basin, and (3) the Narmada basin (Merh 1995; GSI 2001).

The Kachchh and Saurashtra regions have distinct geological settings. The E-W oriented, slightly southerly tilted KRB is a half-graben structure. However, the entire basin can be viewed as an assembly of several sub-basins bound by the E-W oriented uplifts along several major faults, such as NPF, Island Belt Fault (IBF), Kachchh Mainland Fault (KMF), South Wagad Fault (SWF) and NKF and the plains in between (Biswas 1987). The block step faulting within the basin is a major structural feature that is indicative of compressional tectonics within the basin.

The horst structure of the southwest tilted Saurashtra peninsula is a quadrangular block, which is bound on all four sides by major tectonic boundaries (figure 1a). The western boundary fault, sub-parallel to the Dharwar trend in the east, cuts across the Saurashtra Arch, which extends to the southwestern fringe of the peninsula. The NNW-SSE trending Cambay graben and the extension of NNE-SSW trending Delhi-Aravalli trend within the peninsula are the major tectonic features. The Saurashtra peninsula is relatively flat and mostly covered with Deccan lava flows, 
(a)
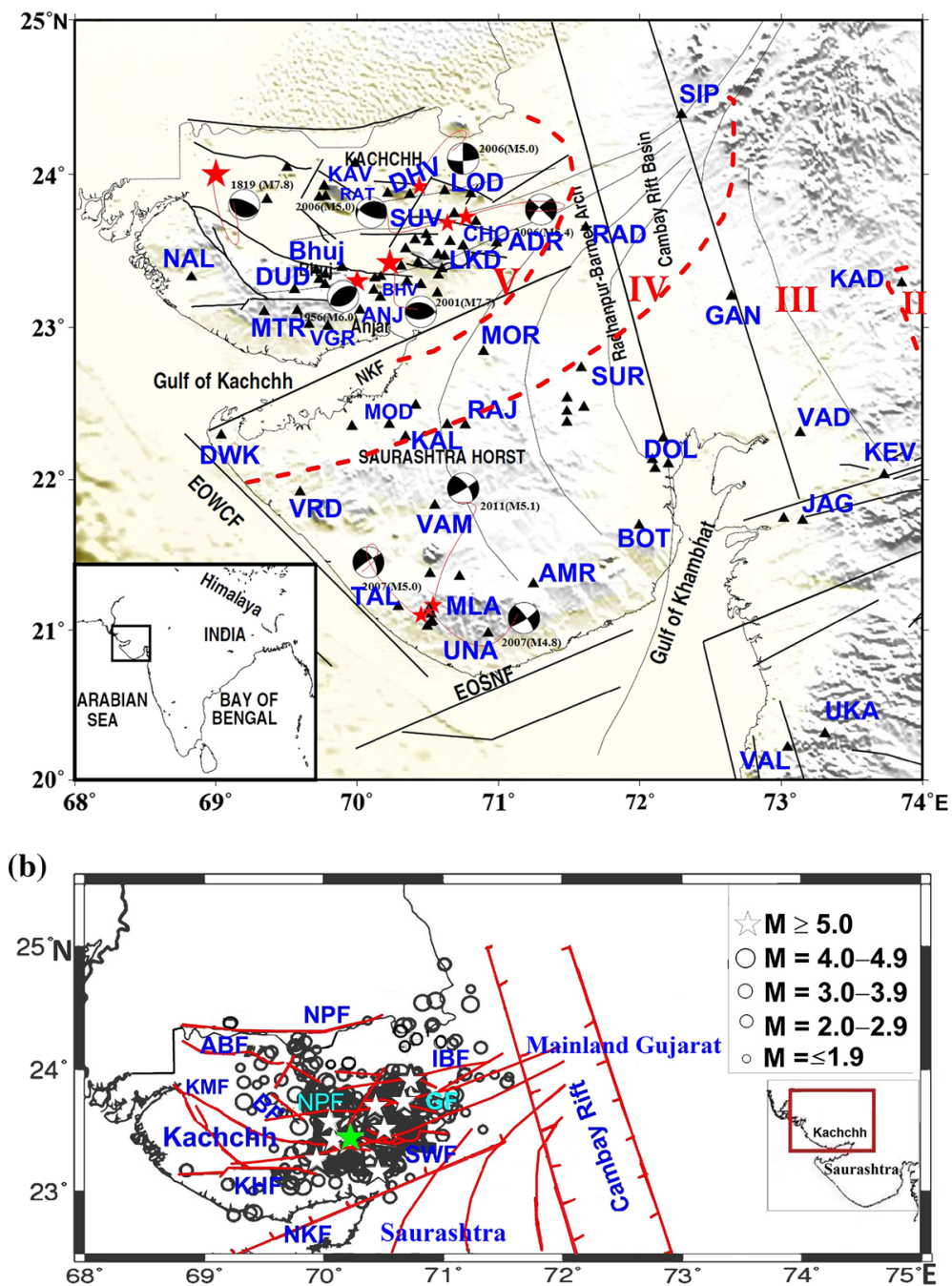

(c)

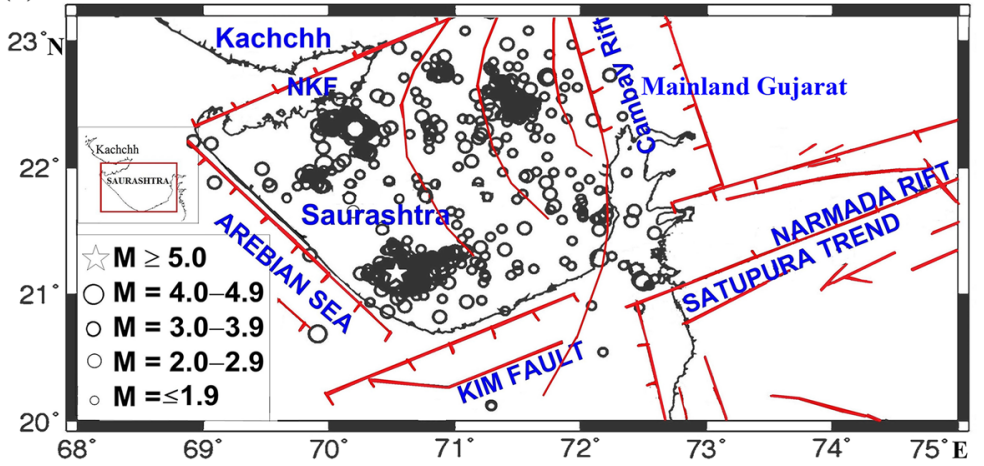

Figure 1. (a) Map showing major tectonic features and past earthquakes with Centroid-moment tensor (CMT) solutions in the study region. Geologically mapped major faults in the Kachchh region are the following: NPF: Nagar Parkar Fault, ABF: Allah Bund Fault, BF: Banni Fault, KMF: Kachchh Mainland Fault, NKF: North Kathiawar Fault, SWF: South Wagad Fault, GF: Gedi Fault, IBF: Island Belt Fault, and the NWF: North Wagad Fault. Triangles show the broadband seismic stations with their station code. Dotted red lines show the seismic zones II-V (BIS 2002). Inset: Location map of the study region. (b) Epicenters of earthquakes in the Kachchh Rift Basin during 2001-2011. Green star shows the 2001 Bhuj Earthquake $\left(M_{w}\right.$ 7.7). (c) Same as figure (b), but for Saurashtra and Mainland Gujarat. 
albeit the presence of sedimentary sequences from Mesozoic and Quaternary in the northern and southern fringes (Merh 1995; Sheth et al. 2012). Other rock types within the Deccan volcanics are intrusive in the form of volcanic plugs and dike swarms; the major intrusive being the Mount Girnar complex (Paul et al. 1977). Using LANDSAT imagery and aerial photography data, Ramasamy (1995) reported existence of several east-west trending lineaments, radiating dike swarms, several Z-shaped, and S-shaped drag folds in the southeastern part of the Saurashtra peninsula.

\section{Data}

The Institute of Seismological Research (ISR) is operating a seismic network in Gujarat since August 2006 (figure 1a; Chopra et al. 2008b). The network comprises broadband seismographs (BBS) as well as Strong Motion Accelerographs (SMA). Sixty seismic stations are equipped with CMG $3 \mathrm{~T}$ broadband sensors (BBS) connected to 24-bit CMG-DM24 Guralp digitizers. The digitizers are synchronized with GPS system for time logging. The BBS data are transmitted through VSAT to the ISR's central station at Gandhinagar, Gujarat.

In the KRB, the aftershock activity of the 2001 Bhuj earthquake is continuing, with the occurrence of several moderate earthquakes (figure $1 \mathrm{~b}$ ). Besides the aftershock activity, several fold increase in seismicity along many other faults in KRB and SH could be due to stress perturbation caused by the 2001 Bhuj mainshock. However, the seismicity has not increased relatively along the Cambay Basin or Narmada zone or in other parts of the Mainland (Rastogi et al. 2014). In the SH, it is observed that seismicity (figure 1c) mostly follows heavy rainfall during the Indian summer monsoon (Singh et al. 2015). In this study, we used about $250\left(M_{w}\right.$ 1.6-5.0) events that occurred in the SH during 2006-2007 and $450\left(M_{w} \quad 1.3-4.8\right)$ events from KRB during 2002-2009. In addition, data of about 300 early aftershocks during August 2002-November 2004 recorded by the National Geophysical Research Institute (NGRI) Seismic Network consisting of eight BBS and ten SMA (Mandal et al. 2006; Sairam 2012) are also used. The seismographs recorded data in a continuous mode at 100 sps, while the accelerographs have been operated in a trigger mode with a sampling frequency of $200 \mathrm{~Hz}$ and a trigger level of
0.00195 gal. However, the NGRI network is confined to the KRB only.

The seismic noise levels are estimated for all the seismic stations in terms of the power spectral density (figures 2-6) and compared with the new global high and low noise models (Peterson 1993). Our calculations show that the day and night-time noise levels are similar, without varying with the time of the day. This is because our seismic stations are away from artificial noise sources like traffic, industrial and cultural noise. The noise levels at hard rock sites are found to be smaller in comparison to those of soft rock or sediment sites (figures 2-6). The noise levels at the Quaternary sediment sites are found to be larger compared to those at sites located on other geological formations. The Deccan trap sites show lesser noise levels, while sites on Jurassic, Cretaceous, and Tertiary formations show moderate noise levels. An earlier study by Kumar et al. (2012) using data from 14 broadband seismic stations revealed that stations on soft soils are noisier. A careful comparison between the previous seismic noise level analysis based on data from limited stations and the present analysis with larger amount of data recorded by more seismograph stations for longer duration, provides detailed information about the background noise level of the Gujarat seismic network. The current results can be used to evaluate the quality of data at the seismic stations and estimate the threshold magnitude detection capabilities.

\section{Methodology}

\subsection{Estimation of source parameters}

In this study, spectral analysis of the transverse component waveforms $\left(\mathrm{S}_{\mathrm{H}}\right)$ is performed using the SEISAN software (Havskov and Ottemoller 1999), to estimate the SPs of earthquakes in the KRB and SH regions. The Fast Fourier Transform is utilized to compute displacement spectra of the instrument corrected $\mathrm{S}_{\mathrm{H}}$-wave data, which are subsequently accounted for the near-surface attenuation ( $K$ value), geometrical spreading and inelastic attenuation effects. A frequency depen$\operatorname{dent} Q=102 f^{0.98}$ (Mandal et al. 2004a) is used to correct for the inelastic attenuation effects. Subsequently, the low-frequency levels and highfrequency spectral decays are determined by fitting 

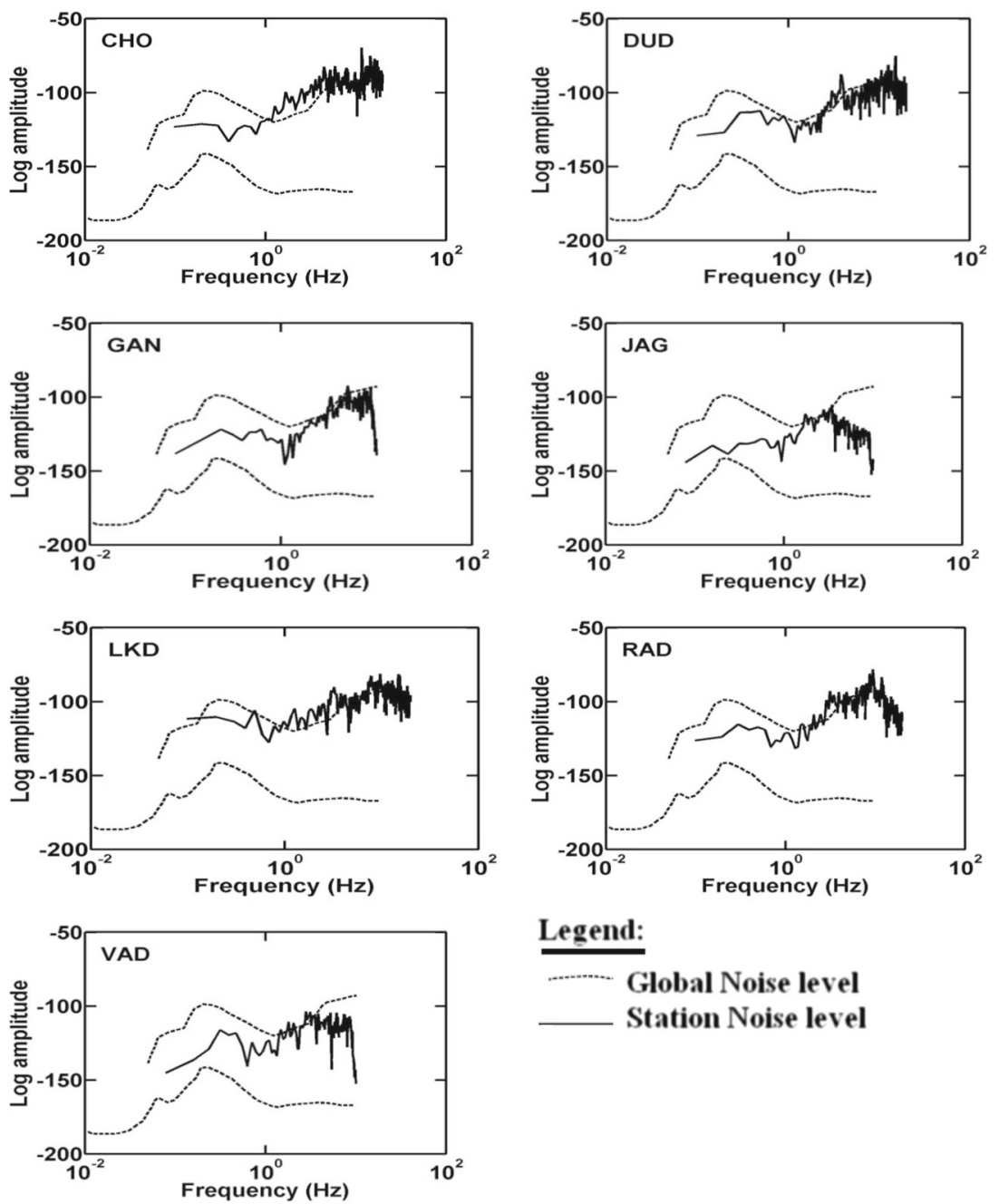

Legend:

Global Noise level

Station Noise level

Figure 2. Estimated seismic noise levels at broadband seismograph (BBS) stations on Quaternary sediments. The BBS stations are CHO: Chobari; DUD: Dudhai; GAN: Gandhinagar; JAG: Jhagadia; LKD: Lakadiya; RAD: Radhanpur and VAD: Vadodara.
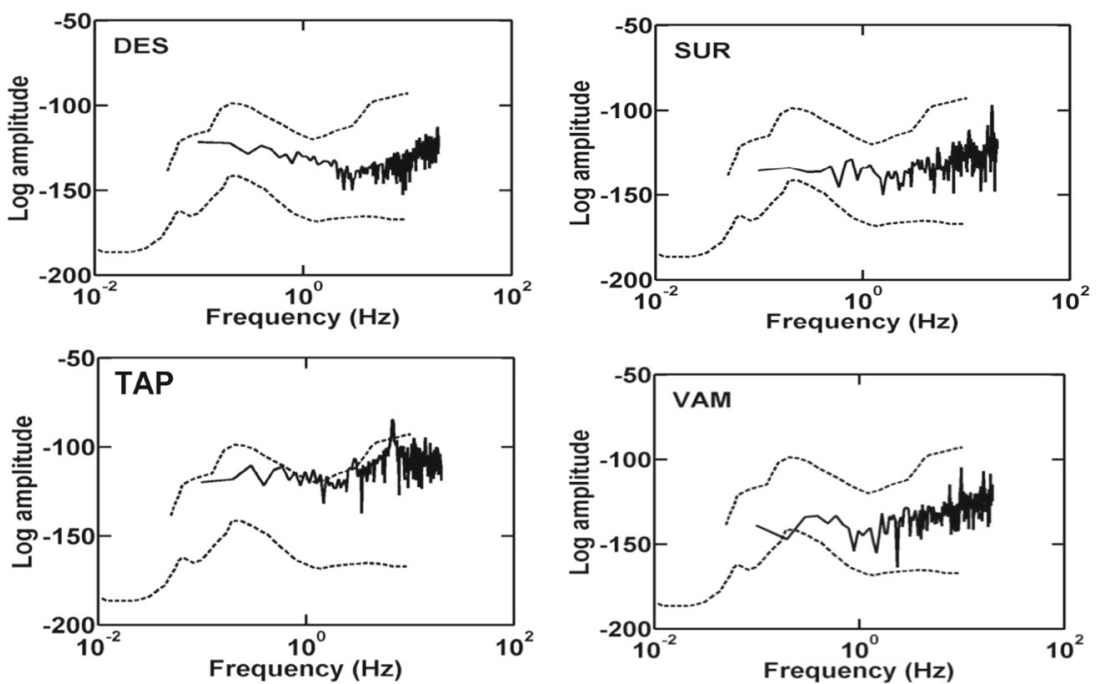

Figure 3. Estimated seismic noise levels at BBS stations on Cretaceous rocks. The BBS stations are DES: Deshalpar; SUR: Surendranagar; TAP: Tapar and VAM: Vamka. 

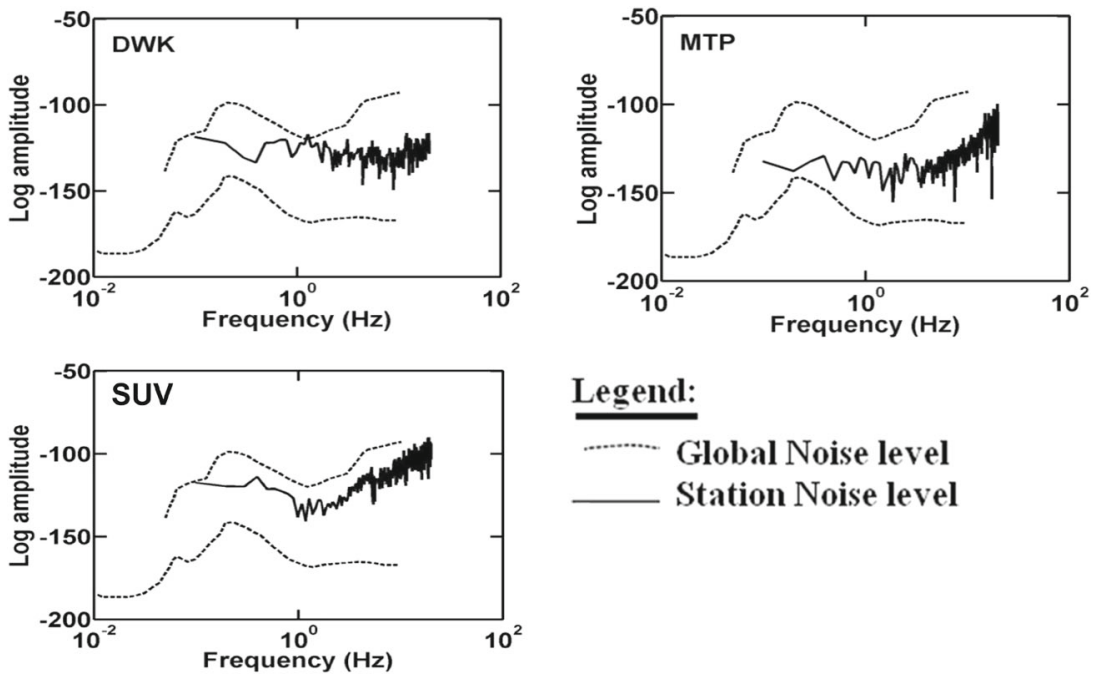

\section{Legend:}

Global...... Noise level

Station Noise level

Figure 4. Calculated seismic noise levels at BBS stations on tertiary rocks. The BBS stations are DWK: Dwarka; MTP: Madhapar and SUV: Suvai.
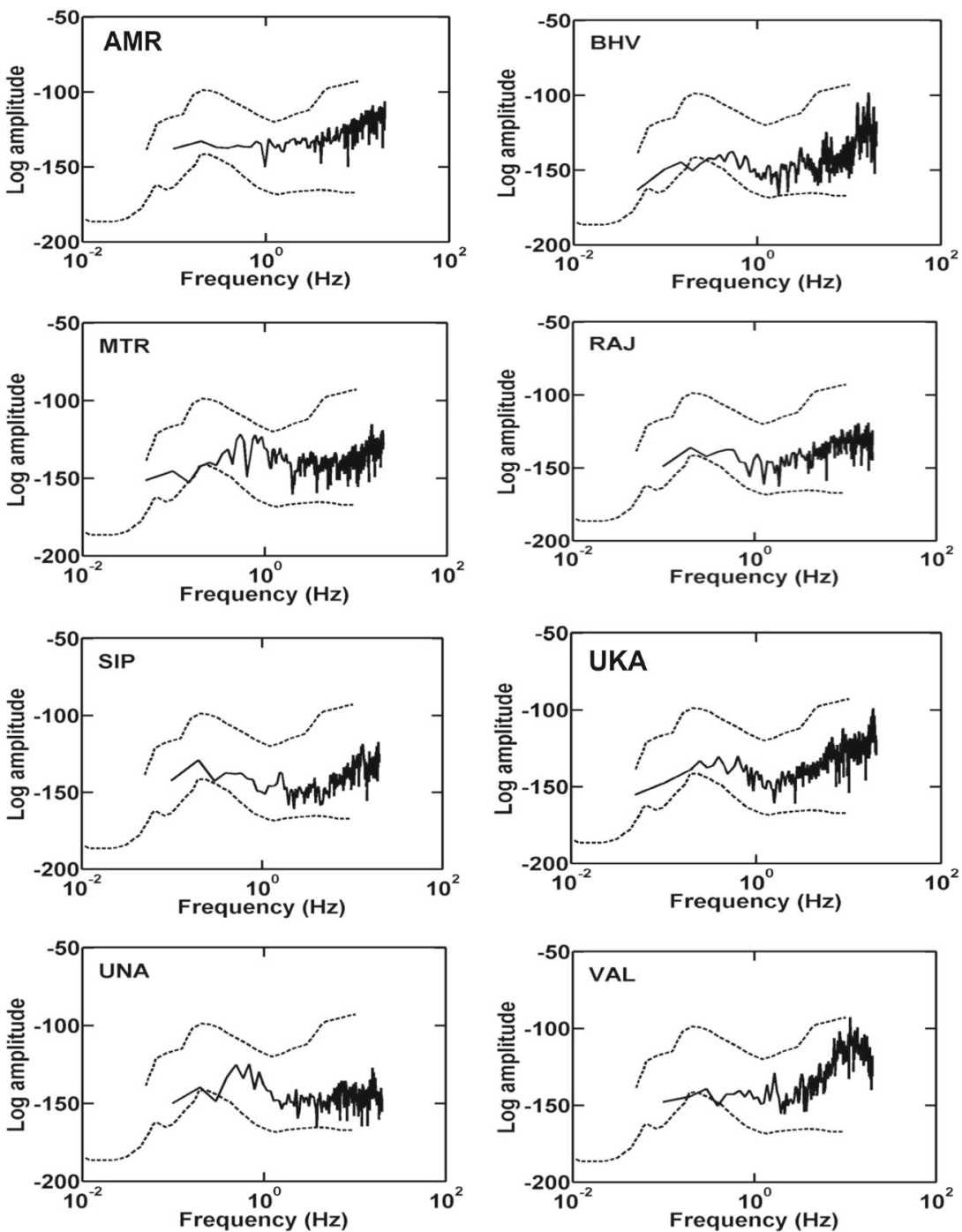

Figure 5. Seismic noise levels at BBS stations on Deccan traps rocks. The BBS stations are AMR: Amerali; BHV: Bhachau; MTR: Matapar; RAJ: Rajkot; SIP: Sipu; UKE: Ukai; UNA: Una and VAL: Valsad. 

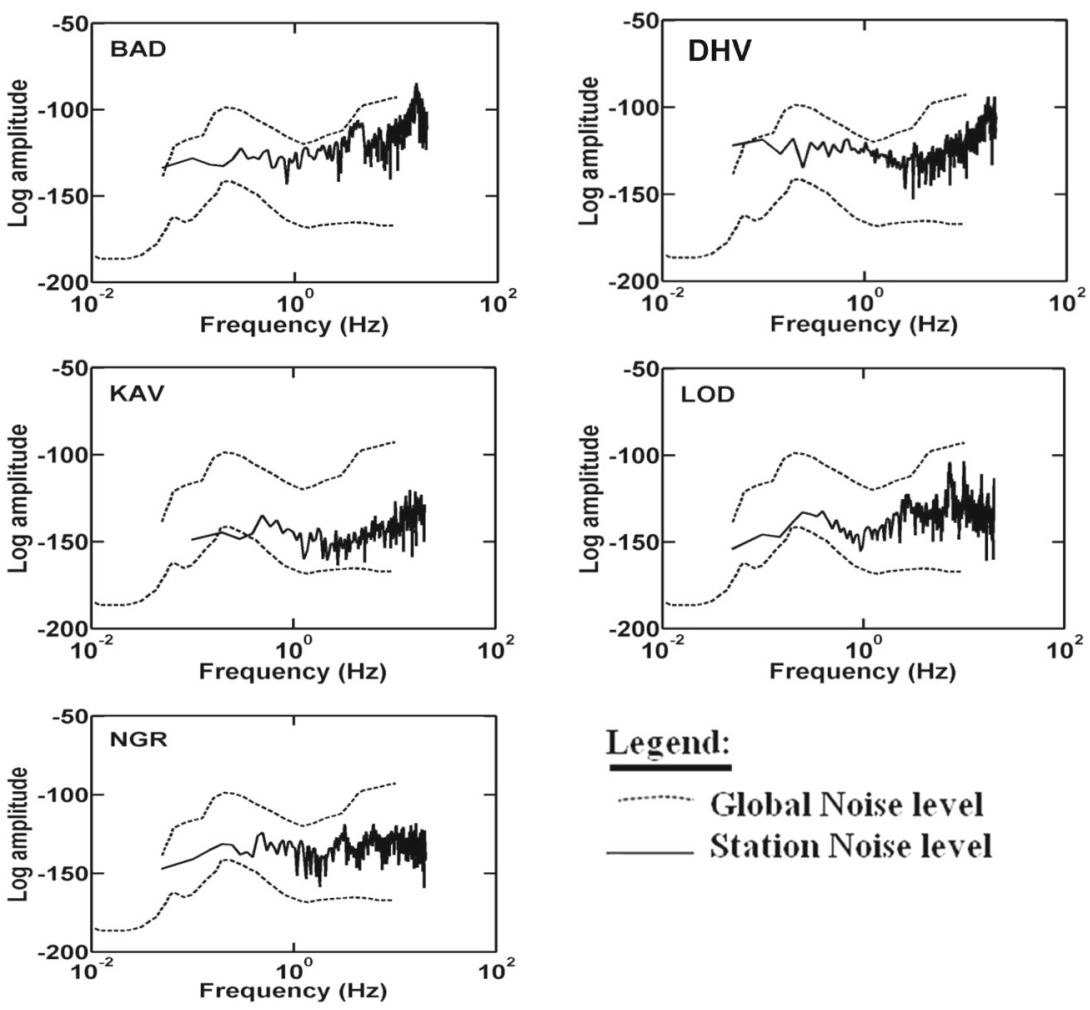

\section{Legend:}

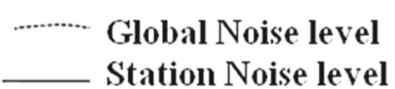

Figure 6. Seismic noise levels at BBS Stations on Jurassic rocks. The BBS stations are BAD: Badalgarh; DHV: Dholavira; KAV: Khavda; LOD: Lodrani and NGR: Nagor.

of two straight lines to the spectra, in a logarithmic form, i.e., $\omega^{-2}$ source spectra (Brune 1970). The corner frequency is obtained from the intersecting point of these two straight lines. Samples of typical displacement spectra are shown in figures 7 and 8.

Following Brune (1970) circular source model, the observed displacement spectrum for an epicentral distance $(d)$ and hypocentral depth $(h)$ can be written as:

$$
d(f)=A(r, h) * D(f) * \frac{M_{o} * R_{\theta \emptyset}}{4 * \pi * \rho * \beta^{3}\left[1+\left(f^{2} / f_{c}^{2}\right)\right]}
$$

where $f_{c}$ is the corner frequency, $M_{o}$ is the seismic moment, and $r$ is the hypocentral distance, $R_{\theta \emptyset}$ is the mean radiation pattern factor $(0.55)$, $\rho\left(2700 \mathrm{~kg} / \mathrm{m}^{3}\right)$ is the density, $\beta$ is the S-wave velocity $(3600 \mathrm{~m} / \mathrm{s})$ and $A(r, h)$ is the geometrical spreading. Since geometrical spreading depends on the hypocentral distance $r$ and depth $h$, the spreading effects are accounted using the relations of $A(r, h)=1 / r$ for $r<100 \mathrm{~km}$ and $A(r, h)=1 /(100 * r)^{1 / 2}$ for $r>100 \mathrm{~km}$ (Herrmann and Kijko 1983; Herrmann 1985). According to
Brune's (1970) circular source model, $D(f)$ is the diminution function due to inelastic attenuation that can be written as:

$$
D(f)=P(f) * \exp \left(-\frac{\pi * f * t}{Q(f)}\right)
$$

where $P(f)=\exp (-\pi * k a p p a * f)$ is meant for near-surface attenuation (Singh et al. 1982). The inelastic attenuation parameter $Q(f)$ accounts for attenuation of seismic waves along the travel path. $Q(f)$ can be written in terms of frequency dependent quality factor $\left(Q_{0}\right)$ as $Q(f)=Q_{0} f^{n}$. In this study, a frequency dependent relation, $Q(f)=102 * f^{0.98}$ (Mandal et al. 2004a) is used for correcting the attenuation effects.

The calculated S-wave displacement spectrum can be written as:

$$
\begin{aligned}
D(f, t) & =\frac{\Omega_{o}}{\left[1+\left(f^{2} / f_{c}^{2}\right)\right]} \\
& =\frac{M_{o} * F * R_{\theta \emptyset}}{4 * \pi * \rho * R * \beta^{3} *\left[1+\frac{f^{2}}{f_{c}^{2}}\right]} .
\end{aligned}
$$

This spectrum is used to obtain low-frequency amplitude level $\left(\Omega_{o}\right)$ and corner frequency $\left(f_{c}\right)$. 

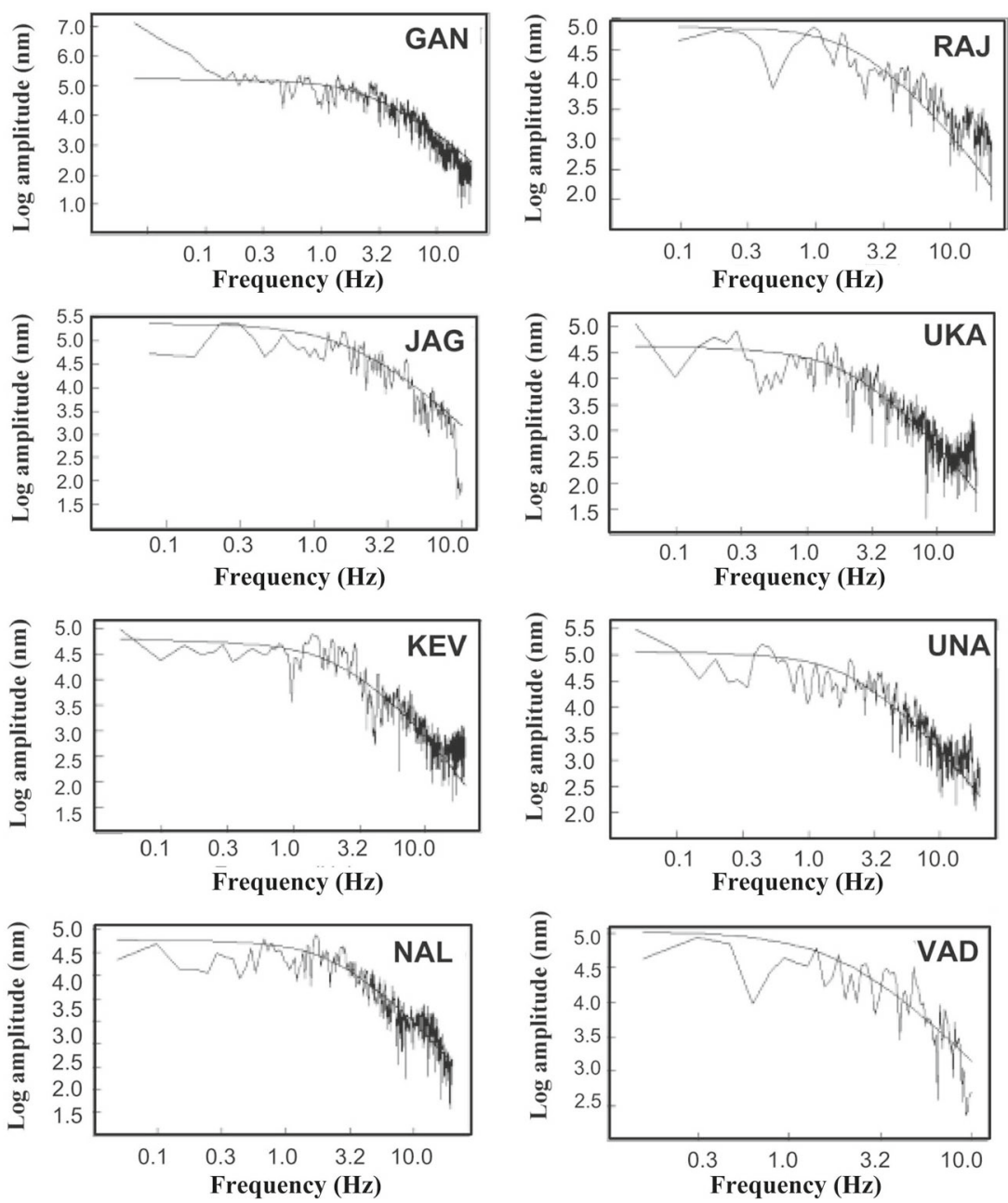

Figure 7. Estimated $\mathrm{S}_{\mathrm{H}^{-}}$wave spectra of an earthquake magnitude of 5.0, which occurred on November 6 , 2007 in the Saurashtra Horst. SPs of this earthquake are estimated at eight BBS stations.
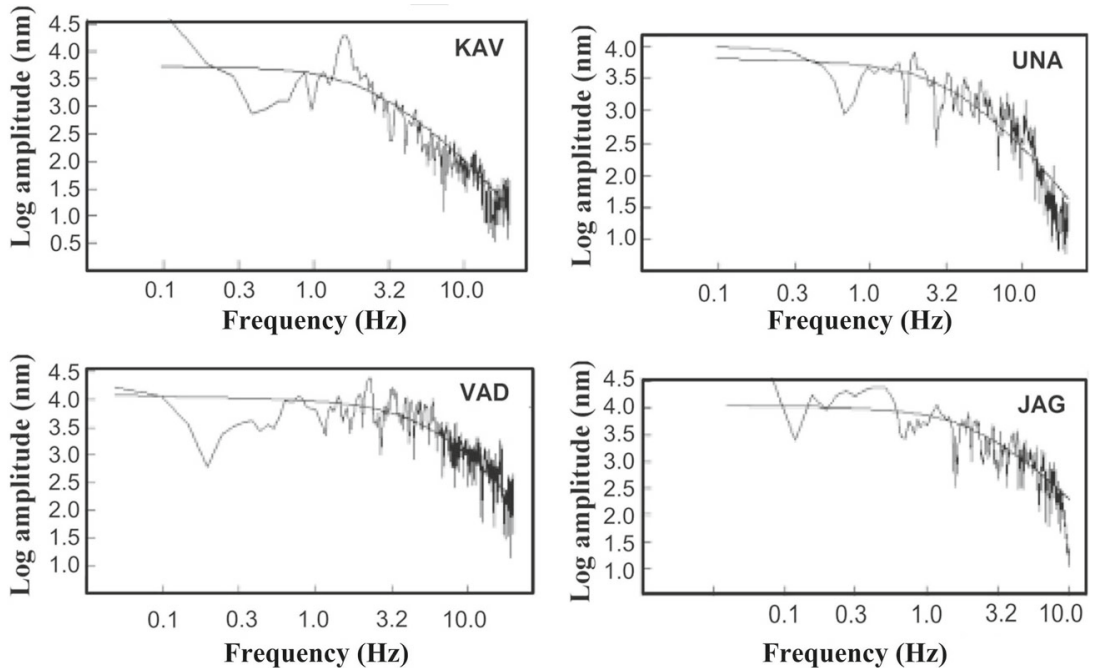

Figure 8. Estimated $\mathrm{S}_{\mathrm{H}}$-wave spectra at different seismic stations for an earthquake magnitude of 4.2 , which occurred on March 1, 2008 in the KRB. 
Then, the other SPs are estimated from the following relations

Seismic moment $\left(M_{o}\right)$

$$
=\frac{4 \pi \rho R \beta^{3}}{F R_{\theta \emptyset}} \Omega_{o} \quad \text { (Brune 1970) }
$$

Source radius $(r)$

$$
=(0.37 \times \beta) / f_{c} \quad \text { (Brune 1970) }
$$

Stress drop $(\Delta \sigma)$

$$
\begin{array}{r}
=\frac{7}{16} \times \frac{M_{o}}{r^{3}} \quad(\text { Borok 1959) } \\
M_{w}=\frac{2}{3} \times \log _{10}\left(M_{o}\right)-6.06
\end{array}
$$

(Hanks and Kanamori 1979)

where $f_{c}$ is in $\mathrm{Hz}, r$ is in $\mathrm{m}, M_{o}$ is in $\mathrm{N}-\mathrm{m}, \Delta \sigma$ is in $\mathrm{MPa}$ and $F$ is the free surface effect, whose value is chosen as 2 .

\subsection{Error estimation of source parameters}

The uncertainties in the SPs estimates are studied by calculating the mean and standard deviation of $f_{c}, M_{o}$, and $\Delta \sigma$ (table 3 ). In our study, the average values of $f_{c}, M_{o}$, and $\Delta \sigma$ for each earthquake are estimated following the formula of Archuleta et al. (1982)

$$
\bar{x}=\operatorname{antilog}\left(\frac{1}{n} \sum_{i=1}^{n} \log x_{i}\right)
$$

where the variable $x$ is $f_{c}$ or $M_{o}$.

The average source radius $(\bar{r})$ is determined utilizing the following equation

$$
\bar{r}=\frac{1}{n} \sum_{i=1}^{n} r_{i}
$$

where $n$ is the number of seismic stations.

The standard deviation can be estimated utilizing the following equation

$$
s d(\log \bar{x})=\left(\frac{1}{n-1} \sum_{i=1}^{n}\left[\log x_{i}-\log \bar{x}\right]^{2}\right)^{1 / 2}
$$

where the variable ' $x$ ' is $f_{c}$ or $M_{o}$.

The multiplicative error factor $E x$ can be determined following the formula of Archuleta et al. (1982)

$$
E x=\operatorname{antilog}\{s d[\log (x)]\} .
$$

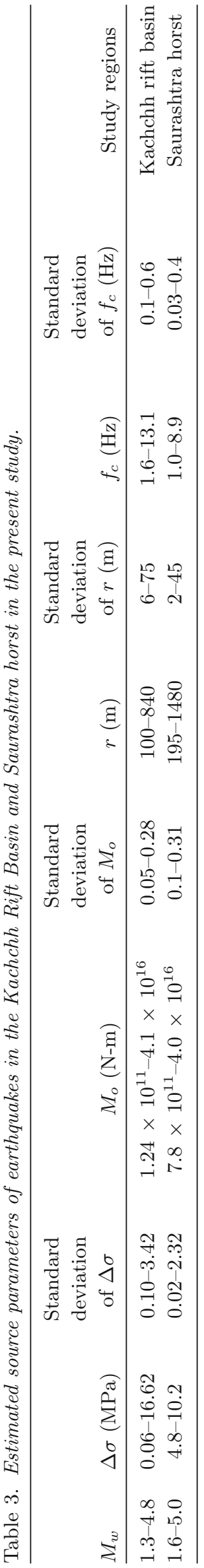


Finally, the standard deviation of $\Delta \sigma$ is estimated following the scheme of Fletcher et al. (1984) utilizing the equation

$$
\sigma_{\text {std }}=\Delta \sigma\left\{\left[\left(\frac{\sigma_{m}}{M_{o}}\right)^{2}+9\left(\frac{\sigma_{r}}{r}\right)^{2}\right]\right\}^{1 / 2}
$$

where $\sigma_{\text {std }}, \sigma_{r}$ and $\sigma_{m}$ are the standard deviations of $\Delta \sigma, r$ and $M_{o}$, respectively.

\subsection{Empirical relationships for the study regions}

Empirical relations for $M_{o}$ vs. $f_{c}, M_{o}$ vs. $r$, and $M_{o}$ vs. $\Delta \sigma$, for both $\mathrm{KRB}$ and $\mathrm{SH}$ regions, were obtained by leastsquare fitting (figure 9a-d; equations 13-21). For the KRB, these relationships are obtained for different sets of magnitude ranges, viz., for $M_{w} 1.5-3.8$ and for $M_{w} \geq 3.9$, since events of this region show a gap at about $M_{w} 3.8$.

Empirical relationships for the $\mathrm{SH}$ region

$$
\begin{aligned}
& \log _{10} M_{o}=16.82-5.39 \log _{10} f_{c} \\
& \log _{10} M_{o}=4.13 \log _{10} r+2.32 \\
& \log _{10} \Delta \sigma=0.62 \log _{10} M_{o}-8.63 .
\end{aligned}
$$

Empirical relationships for the KRB region for $M_{w}$ $1.5-3.8$

$$
\begin{aligned}
& \log _{10} M_{o}=20.64-8.26 \log _{10} f_{c} \\
& \log _{10} M_{o}=6.95 \log _{10} r-2.2 \\
& \log _{10} \Delta \sigma=0.59 \log _{10} M_{o}-7.57 .
\end{aligned}
$$

Empirical relationships for the KRB region for $M_{w} \geq 3.9$

$$
\begin{aligned}
& \log _{10} M_{o}=16.95-3.77 \log _{10} f_{c} \\
& \log _{10} M_{o}=2.78 \log _{10} r+7.8 \\
& \log _{10} \Delta \sigma=0.09 \log _{10} M_{o}-0.4 .
\end{aligned}
$$

\subsection{Estimation of focal mechanisms}

The Isolated Asperity (ISOLA) software is used for performing moment tensor inversion modeling of the broadband waveforms of local and regional earthquakes (Sokos and Zahradnik 2008). ISOLA uses the iterative deconvolution scheme for multiple point sources, developed by Zahradnik et al. (2005). This method is based on an extension of the Kikuchi and Kanamori's (1991) method for local and regional earthquakes. In this method, the Green's functions are computed at local and regional distances using the discrete wave number method of Bouchon (1981) and Coutant (1989). Thus, the method is appropriate for local as well as regional earthquakes. Primarily, a set of point source positions along a line are studied. Subsequently, the contribution from a main point source or sub-event is obtained and then the corresponding synthetics are subtracted from the data. Next, the residual waveform is inverted for another point source, and so on (Zahradnik et al. 2005). As the optimum source position of each sub-event is also to be retrieved, this makes the technique nonlinear. However, because the point sources are removed consecutively, one after another, each step has only two unknown parameters (source position and onset time), thus, contributing to the stability of the inversion (Zahradnik et al. 2005).

In the ISOLA software, a grid search in the area of the accurately located hypocenter is used to obtain the best position and origin time. The grid search provides the optimum sub-event position and time in terms of the absolute value of the correlation coefficient between the observed data and synthetics, which is calculated automatically during the least square inversion (Dimri 1992; Zahradnik et al. 2005). On the best-fitting spatial-temporal position, the match between the observed and synthetic data is characterized by the overall variance reduction (over all stations and components) (Zahradnik et al. 2005; Mandal et al. 2009).

We used band pass filtered $(0.01-5.0 \mathrm{~Hz})$ and instrumentally corrected velocity records as inputs for the ISOLA code. First, ISOLA integrates the input data for estimating the band-passed displacement, which is then used as input for moment tensor inversion. A four point band pass filter (0.05:0.055:0.08:0.1) is used for both observed and synthetic data. The amplitude response of this filter is flat between 0.025 and $0.08 \mathrm{~Hz}$ and cosine tapered between $0.05-0.055$ and $0.08-0.1 \mathrm{~Hz}$. The phase response of the filter is zero. It is important to note that all solutions obtained using ISOLA are close to the first approximation (Zahradnik et al. 2005).

Next, the instrumental corrections on the broadband seismograms are applied using an in-built utility in the ISOLA computer code. Finally, the corrected velocity traces from the origin time to $250 \mathrm{~s}$, filtered between 0.01 and $5.0 \mathrm{~Hz}$ using a 4-pole band pass Butterworth filter, are later integrated to displacement. Finally, these displacement 
(a)

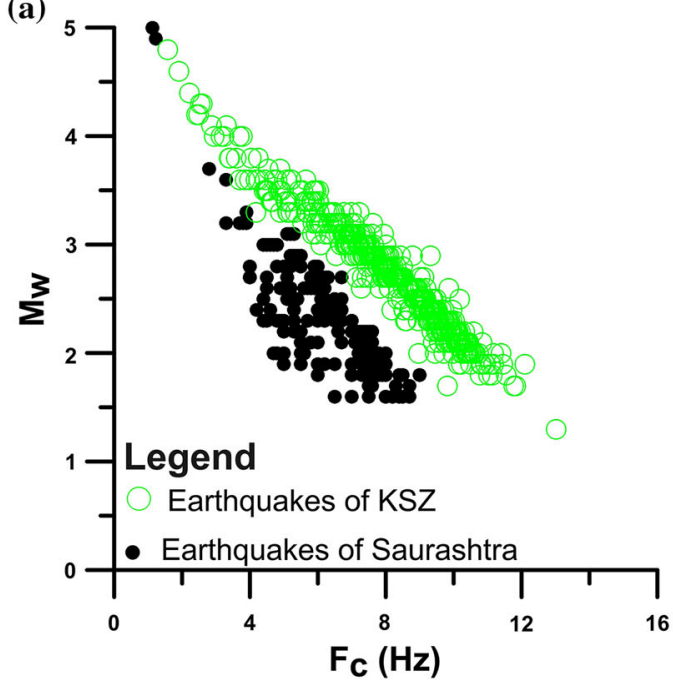

(c)

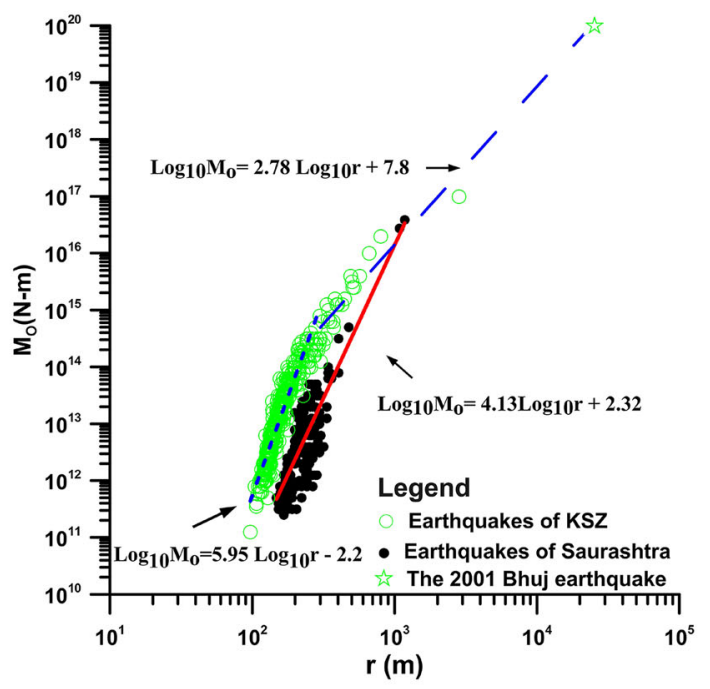

(b)

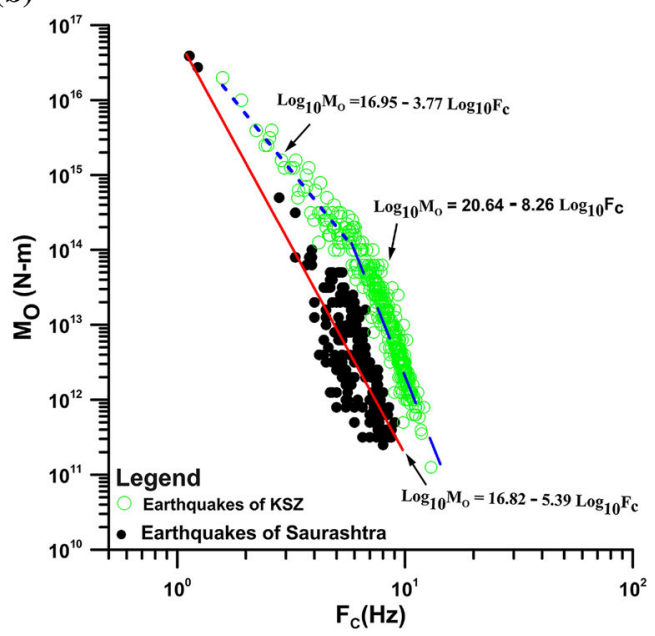

(d)

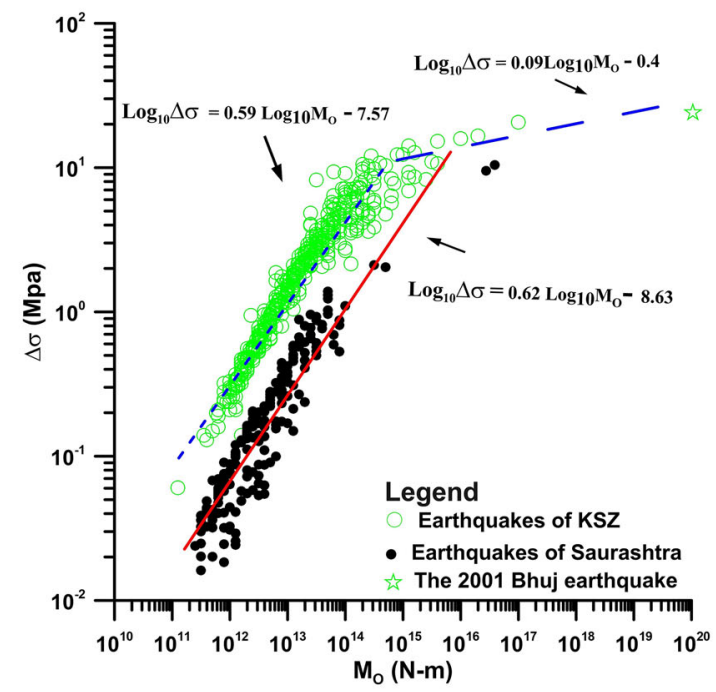

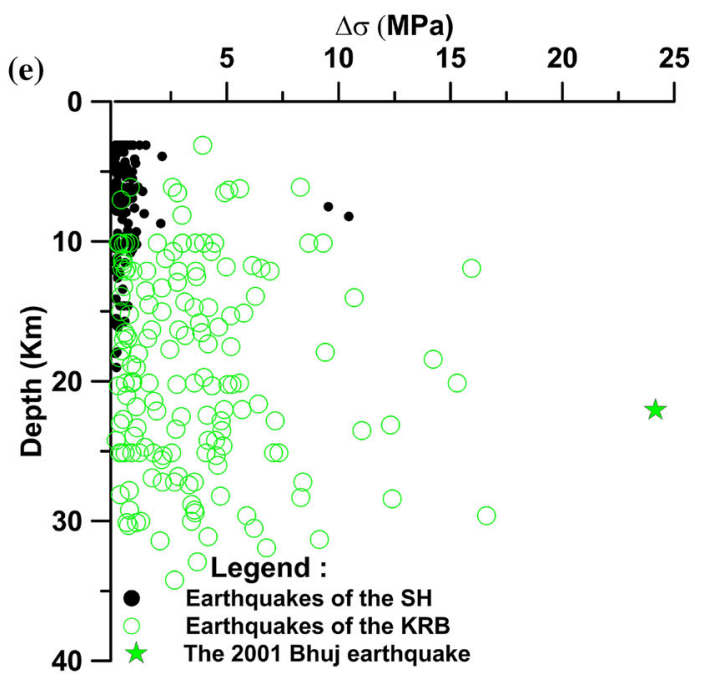

Figure 9. Plotted SPs of the KRB and the SH regions between (a) $f_{c}$ and $M_{w}$, (b) $f_{c}$ and $M_{o},(\mathbf{c}) M_{o}$ and $\Delta \sigma,(\mathbf{d}) r$ and $M_{o},(\mathbf{e})$ depth-wise distribution of stress drops. The large $\Delta \sigma$ values, mostly confined in $15-30$ and $3-8 \mathrm{~km}$ depths, respectively in the KRB and $\mathrm{SH}$. 
traces are used as input data for the full waveform moment tensor inversion, using the velocity model of Mandal et al. (2006) for Green's function calculation.

In general, the seismic moment tensor is used to define the source mechanism of an earthquake. A moment tensor can then be decomposed into the isotropic and deviatoric parts. The isotropic part corresponds to a volume change in the source. The deviatoric part can be decomposed in turn into a Compensated Linear Vector Dipole (CLVD), accounting for non-elastic volume changes and a Double Couple (DC), describing elastic volume changes in the source. Isotropic represents the constant background stress level, while deviatoric represents perturbation in the stress regime.

\section{Results and discussion}

The SPs of earthquakes in the KRB and $\mathrm{SH}$ regions demonstrate that these two tectonic blocks have varied SPs (table 3 ). In the SH, the values of $M_{o}, f_{c}$, $\Delta \sigma$ and $r$ for earthquakes of $M_{w}$ 1.6-5.0 vary from $7.8 \times 10^{11}$ to $4.0 \times 10^{16} \mathrm{~N}-\mathrm{m}, 1.0$ to $8.9 \mathrm{~Hz}$, 4.8 to $10.2 \mathrm{MPa}$ and 195 to $1480 \mathrm{~m}$, respectively (table 3 ; figure $9 \mathrm{a}-\mathrm{e}$ ). The ' $K$ ' value is estimated to be about 0.02. Estimated standard deviations of $\Delta \sigma$ and error factors of the $M_{o}$ and $f_{c}$ for $M_{w} \geq 3.5$ are listed in tables 3 and 4 . The standard deviation of $f_{c}$ varies from 0.03 to $0.4 \mathrm{~Hz} ; r$ from 2.0 to $45.0 \mathrm{~m}$ (table 3 ). The estimated error factor of $M_{o}$ ranges from 0.1 to 1.9 (table 4 ). The estimated standard deviations of $\Delta \sigma$ lie in the range of $0.02-$ $2.32 \mathrm{MPa}$ (table 4). The low standard deviations indicate that the estimated SPs are statistically well estimated. In the $\mathrm{SH}$ region, the magnitude dependency of $f_{c}, \Delta \sigma, M_{o}$ and $r$ can be seen from the relations between $f_{c}$ vs. $M_{w}, \log _{10}\left(M_{o}\right)$ vs. $\log _{10}(\Delta \sigma)$, and $\log _{10}(r)$ vs. $\log _{10}\left(M_{o}\right)$, respectively (figure 9a-e, equations 13-21). The earthquake hypocenters are mainly confined to a depth range of $3-20 \mathrm{~km}$. However, higher $\Delta \sigma(>2.0 \mathrm{MPa})$ values are found for earthquakes that occurred in the depth range of $3-10 \mathrm{~km} ; \Delta \sigma \sim 9.3 \mathrm{MPa}$ for an earthquake of $M_{w} 4.9$ and $\Delta \sigma \sim 10.2 \mathrm{MPa}$ for $M_{w}$ 5.0 , which suggests that the seismogenic layer is in the depth range of $3-10 \mathrm{~km}$ in the $\mathrm{SH}$, which is also supported by previous studies (Yadav et al. 2011; Singh et al. 2015).

In the KRB region, the estimated $M_{o}, f_{c}, \Delta \sigma$ and $r$ for the aftershocks in the range of $M_{w}$ $1.3-4.8$ vary from $1.24 \times 10^{11}$ to $4.1 \times 10^{16} \mathrm{~N}-\mathrm{m}$,
1.6-13.1 Hz, 0.06-16.62 MPa and 100-840 m, respectively (figure $9 \mathrm{a}-\mathrm{e}$ ). The estimated standard deviations of $f_{c}, r$ and $\Delta \sigma$ are in the range of 0.1 $0.6 \mathrm{~Hz}, 6-75 \mathrm{~m}$ and 0.1 to $3.42 \mathrm{MPa}$, respectively (table 3). The error factor of $M_{o}$ estimates are found to be between 1.0 and 1.87 (table 4). The $K$ value is found to be in the range of 0.025 0.03 ; this value correlates well with the ' $K$ ' value estimated earlier by Mandal and Johnston (2006). The large $K$ value could be due to the thick top sedimentary layer in the KRB. Systematic magnitude dependencies of $f_{c}, r, M_{o}$ and $\Delta \sigma$ are also seen from the relation between $f_{c} v s . M_{w}, \log _{10}\left(M_{o}\right) v s$. $\log _{10}(\Delta \sigma)$, and $\log _{10}(r)$ vs. $\log _{10}\left(M_{o}\right)$, respectively (figure $9 \mathrm{a}-\mathrm{e}$ ). The $\log _{10}\left(M_{o}\right)$ vs. $\log _{10}(r)$ plot for the earthquakes of KRB shows a break in linear scaling between $M_{o}$ and ' $r$ ' at $M_{o}=10^{14.9} \mathrm{~N}-\mathrm{m}$ (figure 9d), which is closer to $M_{o} \sim 10^{14.5} \mathrm{~N}-\mathrm{m}$ observed by Mandal and Johnston (2006). Such type of break has not been observed for the other stable continental region earthquakes in the world (Mandal and Johnston 2006; Mandal and Dutta 2011). The large stress drops estimated by us are mainly confined to the main rupture zone of the 2001 Bhuj earthquake between 10 and $30 \mathrm{~km}$ depth (figure 9e), which probably suggests that the base of the seismogenic layer is lying at $30 \mathrm{~km}$ depth as also indicated by the larger $\Delta \sigma$ values $(>15 \mathrm{MPa}$, figure 9e). It is noticed that in the KRB, seismicity extends down to a depth of $40 \mathrm{~km}$ (figure $9 \mathrm{e}$ ) and in the $\mathrm{SH}$ down to a depth of $20 \mathrm{~km}$ only (figure $9 \mathrm{e}$ ).

Furthermore, we estimated focal mechanism solutions of nine earthquakes of $M_{w} 3.5-4.5$, which occurred along the North Wagad Fault (NWF), Gedi fault (GF) and Gora Dungar fault (GDF). Among the nine events, six events are associated with the NWF, two events with the GF, one event with the GDF. Details of focal mechanism solutions of these selected events are given in table 5. For all the events in Kachchh, the nodal plane having a strike between NW-SE and E-W directions, with a dip towards the south, is considered as the fault plane, since it is consistent with the near east-west trending faults of the region. Most of the events show reverse mechanism with a minor strike-slip component (Mandal et al. 2007; Singh et al. 2016). However, one event along the NWF shows normal faulting with a minor strike-slip component. The estimated CMT solutions obtained in this study are consistent with those from previous studies (Mandal et al. 2007; Rao et al. 2013; Singh et al. 2016).

In the $\mathrm{SH}$ region, focal mechanism solutions of two earthquakes of $M_{w} 4.0$ and 5.3, which occurred 


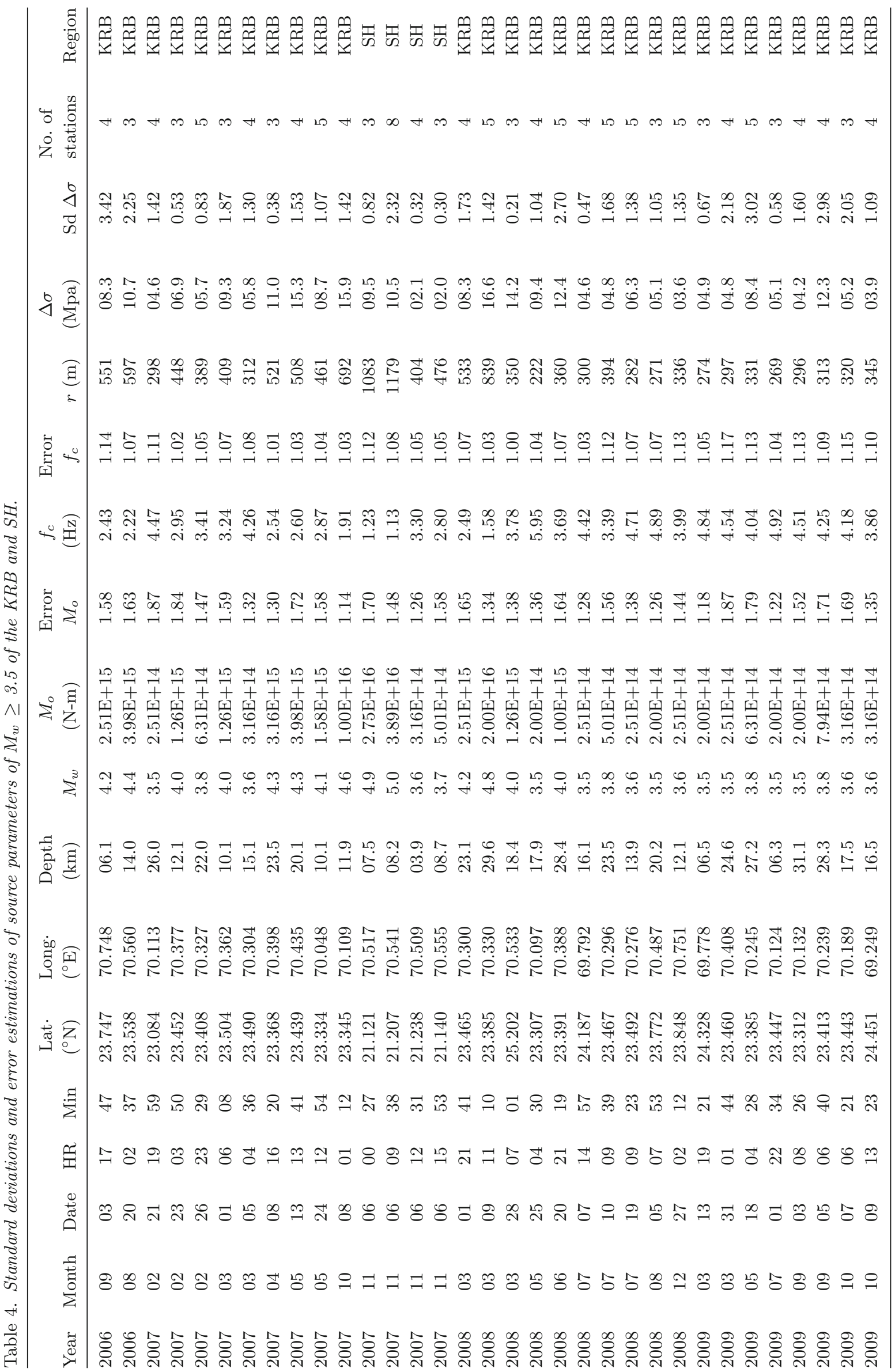




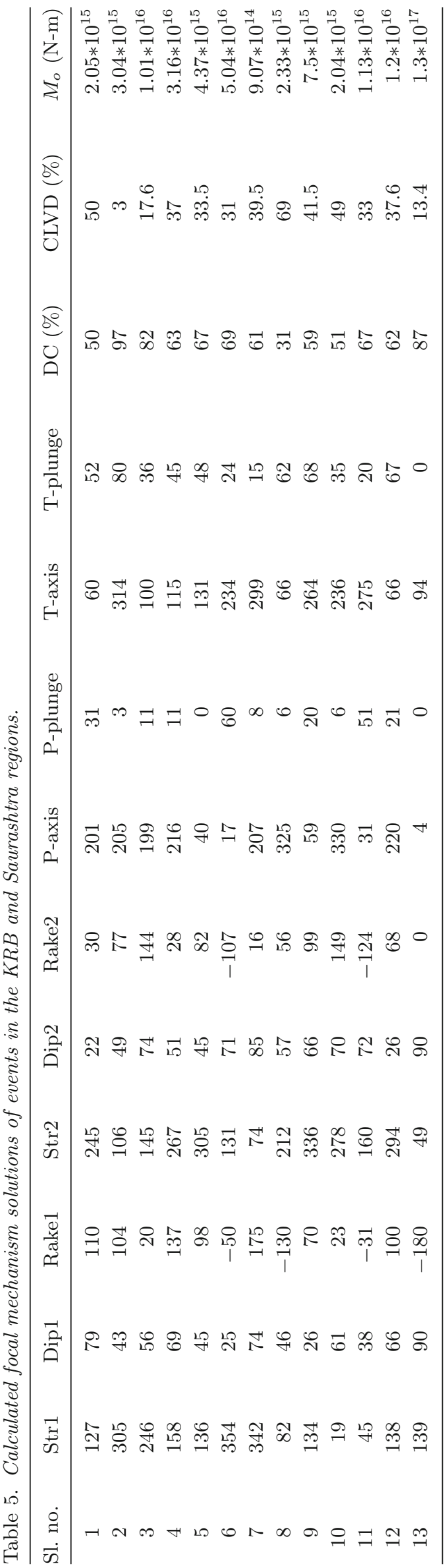

along NW-SE trending lineaments, are estimated. The nodal plane which strikes in the NW-SE direction and dipping steeply towards south is considered as the fault plane, since it is consistent with the near NW-SE trending lineaments of the region (figure 10a-b). The CMT solution of an earthquake $M_{w} 5.3$ near Junagadh in 2011 shows a pure strikeslip mechanism, while the CMT solution of an earthquake $M_{w} 4.0$ near Jamnagar in 2006 reveals a reverse mechanism with a minor strike-slip component.

Although different kinds of CMT solutions are found (figure 10a, table 5), they show two major trends. For most of the earthquakes, one of the nodal planes strikes in an east-west to northwestsoutheast direction favoring a reverse mechanism with a minor right-lateral strike-slip component. The orientation of $\mathrm{P}$-axis is nearly NNE-SSW, with some scatter (figure 10b). It implies that the estimated compressive stress direction being in the direction of Indian plate motion may cause a state of high compressive stress in different parts of the study regions.

Higher stress drops normally reflect material as well as structural heterogeneity, which is more evident in Kachchh compared to that in the SH. This is supported by more aftershock activity and thrust dominated right-lateral movement. Seismic tomographic studies in both the regions reveal why and how the structural heterogeneities control the earthquakes genesis (Kayal et al. 2002; Mandal et al. 2004b; Singh et al. 2012; Singh and Mishra 2015). Interestingly, the seismic activity in the $\mathrm{SH}$ has been drastically enhanced after the 2001 Bhuj earthquake, suggesting the reactivation of hidden seismogenic faults or creation of a new-seismic regime because of a long series of continued aftershock sequences of the Bhuj earthquake. Furthermore, the pattern of distribution of seismic velocity in Talala, $\mathrm{SH}$ and its association with aftershock occurrence provide seismological evidence for the neo-tectonics in the region, with a left-lateral strike-slip motion on the faults (Singh et al. 2013; Singh and Mishra 2015). The rate of occurrence of micro to moderate shallow earthquakes $(\leq 20 \mathrm{~km})$ enhances after heavy rainfall in the Indian summer monsoon period (Singh and Mishra 2015), which supports the explanation of pore collapse in the saturated subsurface rock matrix. The heavy rainfall raises the ground water table by $12-17 \mathrm{~m}$ in the observation wells, which was measured by the State Ground Water Department of Gujarat. In general, the rise of 


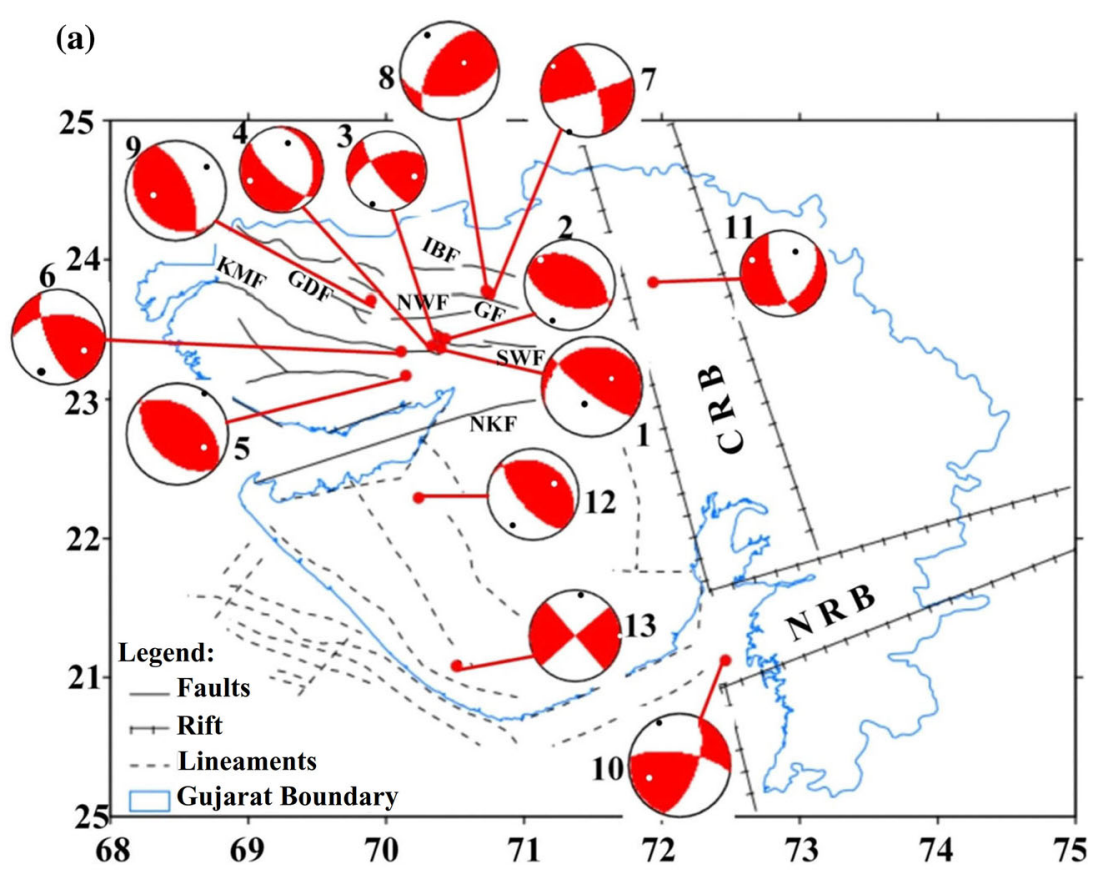

(b)

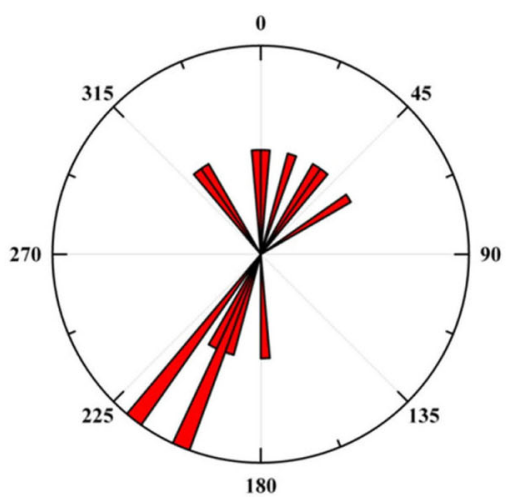

Figure 10. (a) Estimated focal mechanism solutions in Kachchh, Saurashtra and Mainland Gujarat regions. Red coloured dots represent the events numbered 1-13. Open and black circles in the fault plane solutions represent T- and P-axes, respectively. Narmada Rift Basin (NRB), Cambay Rift Basin (CRB), KMF, SWF, NKF. (b) Rose diagram of the P-axis.

the groundwater table to about $10 \mathrm{~m}$ can induce stresses of the order of one bar (Singh and Mishra 2015). Thus, a stress change of 1-2 bars due to the rise in the groundwater table in the region can be considered sufficient to trigger small tremors along pre-existing critically stressed faults. The estimated lower stress drops may be caused due to triggering effect. Thus, we feel that the strikeslip mechanisms and relatively lower stress drops of the $\mathrm{SH}$ could be explained in terms of seismic failure on pre-existing small faults, such as the left-lateral strike-slip Umrethi fault at a shallow depth in the Talala region (Singh et al. 2015). A correlation of low-stress drop with strike-slip events is observed in the SH. In contrast, the highstress drops in the KRB are predominantly associated with the reverse with a slight component of strike-slip mechanism. In the KRB, earthquakes near the epicenter of the 2001 mainshock primarily show reverse faulting mechanism (Mandal 2008; Singh et al. 2016). The surrounding earthquakes in the area, however, show predominantly strike-slip mechanisms (Rao et al. 2013; Singh et al. 2016).

We have obtained empirical relationships among $M_{o}, f_{c}, r$ and $\Delta \sigma$ (equations 13-21), which are very important to understand the nature of self similarity of earthquakes (Kanamori and Anderson 1975; Hanks 1977). Our present study revealed $M_{o} \propto f_{c}^{-5.39}$ for the SH region (equation (13), figure 9b). Similarly, the two empirical relationships for the KRB are $M_{o} \propto f_{c}^{-8.26}$ and $M_{o} \propto$ $f_{c}^{-3.77}$ for events between $M_{w} 1.5-3.8$ and $M_{w} \geq$ 3.9 (equations 16 and 19, figure 9b), respectively. From these relations, it is inferred that 
Table 6. Empirical relationship between $M_{o}$ and $f_{c}$ of the intraplate and interplate earthquakes of the Indian region.

\begin{tabular}{|c|c|c|c|}
\hline Equation $\left(\mathrm{N}-\mathrm{m} / \mathrm{s}^{3}\right)$ & Earthquakes & $M_{w}$ & References \\
\hline$M_{o} f_{c}^{3}=7.6 * 10^{16}$ & $\begin{array}{l}\text { Aftershocks of the } 2001 \\
\text { Bhuj earthquakes }\end{array}$ & $3.3-4.9$ & Kumar et al. (2014) \\
\hline$M_{o} f_{c}^{3}=4.14 * 10^{18}$ & $\begin{array}{l}\text { Aftershocks of the } 2001 \\
\text { Bhuj earthquakes }\end{array}$ & $2.93-5.32$ & Mandal and Dutta (2011) \\
\hline$M_{o} f_{c}^{6.13}=9 * 10^{1617}$ & $\begin{array}{l}\text { Aftershocks of the } 2001 \\
\text { Bhuj earthquakes }\end{array}$ & $2.0-4.0$ & Kumar et al. (2015) \\
\hline$M_{o} f_{c}^{9.748}=10^{22}$ & $\begin{array}{l}\text { Aftershocks of the } 2001 \\
\text { Bhuj earthquakes }\end{array}$ & $4.0-5.2$ & Kumar et al. (2015) \\
\hline$M_{o} \propto f^{-3.6}$ & $\begin{array}{l}\text { Earthquakes of Sikkim } \\
\text { Himalaya }\end{array}$ & $4.0-5.3$ & Hazarika and Kumar (2012) \\
\hline$M_{o} f_{c}^{8.26}=4.36 * 10^{20}$ & $\begin{array}{l}\text { Aftershocks of the } 2001 \\
\text { Bhuj earthquakes }\end{array}$ & $1.5-4.0$ & In this study \\
\hline$M_{o} f_{c}^{3.49}=6.3 * 10^{16}$ & $\begin{array}{l}\text { Aftershocks of the } 2001 \\
\text { Bhuj earthquakes }\end{array}$ & $4.0-5.2$ & In this study \\
\hline$M_{o} f_{c}^{5.39}=6.6 * 10^{16}$ & Earthquakes of the $\mathrm{SH}$ & $1.6-5.0$ & In this study \\
\hline
\end{tabular}

earthquakes of the $\mathrm{KRB}$ and $\mathrm{SH}$ do not follow the law of self similarity (Mandal and Dutta 2011; Kumar et al. 2015). However, the study of Kumar et al. (2014), shows self similarity for the earthquakes of $M_{w}$ 3.3-4.9. The difference in the nature may be due to different size of events and non-consideration of the break in source parameters (Kumar et al. 2015). Similarly, Hazarika and Kumar (2012) reported that earthquakes in Sikkim Himalaya do not show self similarity. From table 6, it is observed that most of the intraplate and interplate earthquakes within the Indian subcontinent do not follow self similarity. We have developed empirical relationships between $M_{o}$ and $r$, which show that $M_{o} \propto r^{4.13}$ for events in the $\mathrm{SH}$ region (equation 14, figure 9c), while $M_{o} \propto r^{6.95}$ (for $M_{w} \sim 1.5-3.8$ ) and $M_{o} \propto r^{2.78}$ (for $M_{w} \geq 3.9$ ) for earthquakes in the KRB (equations 17 and 20, figure 9c). It is observed that the source radius of the $\mathrm{SH}$ events is higher than those for the KRB earthquakes (figure 9c). The relationship between $\Delta \sigma$ and $M_{o}$ shows that $\Delta \sigma \propto M_{o}^{0.62}$ for the $\mathrm{SH}$ events (equation 15, figure 9d), while $\Delta \sigma \propto M_{o}^{0.59}$ (for $M_{w} \sim 1.5-3.8$ ) and $\Delta \sigma \propto M_{o}^{0.09}$ (for $M_{w} \geq 3.9$ ) for the KRB earthquakes (equations 18 and 21, figure 9d). It is noticed that earthquakes in KRB have higher stress drop values compared to the quakes in $\mathrm{SH}$ region.

Furthermore, we compared the SPs of earthquakes in the KRB and $\mathrm{SH}$ regions with other intraplate and interplate earthquakes of the Indian subcontinent (table 7). Several researchers determined stress drops of different earthquakes in the Indian region, such as the 1993 Latur $\left(M_{w}\right.$ 6.2), 1997 Jabalpur ( $M_{w}$ 5.8), Koyna earthquake sequence and interplate earthquakes. Estimates show that stress drops vary between 2 and 25 $\mathrm{MPa}$ for most of the earthquakes in the Indian region (table 7 ), which are supported by results from this study. It is interesting to note that the estimated $M_{o}$ and $\Delta \sigma$ values of the $\mathrm{SH}$ events show values nearly similar to the shocks in the Koyna region known for reservoir triggered seismicity (Mandal et al. 1998). The values of the 2001 Bhuj aftershocks are found to be slightly larger than those for the $\mathrm{SH}$ events and reservoir triggered Koyna events (figure 9d; tables 3 and 7). It is believed that the SPs of the Koyna and SH regions are similar in nature. The seismicity in the Koyna and Saurashtra regions is reservoir induced and monsoon-induced, respectively (Gupta 1985; Singh and Mishra 2015). For an $M_{w} 4.8$ Kachchh earthquake, the $\Delta \sigma$ is estimated to be about 16.6 $\mathrm{MPa}$ while the $\Delta \sigma$ for a similar size Saurashtra event of $M_{w} 4.8$ is found $10.2 \mathrm{MPa}$. Nevertheless, the estimated $\Delta \sigma$ values are significantly varied in both regions, probably due to several reasons such as variability in the source geometry, rupture speed, focal depth, local wave velocities, and also uncertainty in the corner frequency (Huang et al. 2017). The higher $\Delta \sigma$ values associated with the KRB events could be attributed to the presence of high velocity mafic intrusive bodies at deeper depths (Mandal et al. 2004b; Singh et al. 2012; Rastogi et al. 2014). 
Table 7. Calculated stress drops of the intraplate and interplate earthquakes in the Indian region.

\begin{tabular}{|c|c|c|c|c|}
\hline $\begin{array}{l}\text { Stress drop } \\
(\Delta \sigma) \mathrm{MPa}\end{array}$ & Earthquake & $\begin{array}{l}\text { Intraplate/ } \\
\text { interplate }\end{array}$ & $\begin{array}{c}\text { Magnitude/ } \\
M_{w}\end{array}$ & References \\
\hline $0.03-19$ & The Koyna earthquakes (1994-1997) & Intraplate & $1.5-4.7$ & Mandal et al. (1998) \\
\hline $3-26$ & The Koyna earthquakes (2005-2012) & Intraplate & $3.5-5.2$ & Yadav et al. (2013) \\
\hline 19 & The 2005 Koyna earthquake & Intraplate & 5.1 & Kumar et al. (2006) \\
\hline 7 & The 1993 Latur earthquake & Intraplate & 6.2 & Baumbach et al. (1994) \\
\hline 4 & The 1991 Uttarkashi earthquake & Interplate & 6.8 & Singh et al. (2003) \\
\hline $0.03-3.37$ & The Kumaon Himalaya earthquakes (2005-2008) & Interplate & $2.7-4.5$ & Sivaram et al. (2013) \\
\hline 15 & The 1999 Chamoli earthquake & Interplate & 6.5 & Singh et al. (2003) \\
\hline 20 & The 1997 Jabalpur earthquake & Intraplate & 5.8 & Singh et al. (2003) \\
\hline
\end{tabular}

\section{Conclusions}

We analyzed the SPs of small to moderate earthquakes in the Kachchh and Saurashtra regions recorded by the Gujarat seismic network over a period of seven years from 2002 to 2009. Results reveal higher stress drops in Kachchh probably due to strong material heterogeneity at the brittleductile transition zone, associated with the intracontinental Kachchh failed rift basin. On the other hand, the present study suggests that earthquakes in the $\mathrm{SH}$ region that occur within a depth of $20 \mathrm{~km}$ are associated with lower stress drops. The estimated $M_{o}$ and $\Delta \sigma$ values in the KRB are slightly larger than those observed for similar magnitude events in Koyna and SH. However, the values are similar in Koyna and Saurashtra. The estimated ' $K$ ', and stress drop values provide a better understating of the seismic characteristics of different seismogenic structures and are useful for risk evaluation in different segments. In general, low-stress drops are observed for regions associated with strike-slip motion.

\section{Acknowledgements}

We sincerely thank the Editor-in-Chief and the two anonymous reviewers for their constructive comments that improved the manuscript. We are also grateful to the Technical staff of ISR, Gandhinagar for their support. BS is thankful to B K Rastogi, Ex-Director General, ISR and Prantik Mandal, NGRI, Hyderabad for their valuable suggestions and discussions. The study was partially supported by Department of Science and Technology (DST), Government of Gujarat and the Ministry of Earth Science, New Delhi, India.

\section{References}

Abercrombie R and Leary P 1993 Source parameters of small earthquakes recorded at $2.5 \mathrm{~km}$ depth, Cajon Pass, southern California: Implications for earthquake scaling; Geophys. Res. Lett. 20 1511-1514.

Aki K 1967 Scaling law of seismic spectrum; J. Geophys. Res. 72 1217-1231.

Akinci A, D'Amico S, Malagnini L and Mercuri A 2013 Scaling earthquake ground motions in western Anatolia, Turkey; Phys. Chem. Earth., Parts A/B/C 63 124-135.

Antolik M and Dreger D S 2003 Rupture process of the 26 January $2001 \mathrm{Mw} 7.6 \mathrm{Bhuj}$, India, Earthquake from teleseismic broadband data; Bull. Seismol. Soc. Am. 93 1235-1248.

Archuleta R J, Cranswick E, Mueller C and Spudich P 1982 Source parameters of the 1980 Mammoth Lakes, California, earthquake sequence; J. Geophys. Res. Solid Earth 87 4595-4607.

Baumbach M, Grosser H, Schmidt H G, Paulat A, Rietbrock A, Rao C V R K, Solomon P R, Sarkar D and Mohan I 1994 Study of foreshocks and aftershocks of the intraplate earthquake of September 30, 1993, India; Geol. Soc. India Memoir 35 33-66.

BIS 2002 Indian standard criteria for earthquake resistant design of structures: Part 1. General provisions and buildings (Fifth Revision), IS 1893 (Part 1): 2002; Bureau of Indian Standards (BIS), New Delhi, India.

Biswas S K 1987 Regional tectonic framework, structure and evolution of the western marginal basins of India; Tectonophys. 135 307-327.

Biswas S K 2005 A review of structure and tectonics of Kutch basin, western India, with special reference to earthquakes; Curr. Sci. 88 1592-1600.

Bodin P and Horton S 2004 Source parameters and tectonic implications of aftershocks of the Mw 7.6 Bhuj Earthquake of 26 January 2001; Bull. Seismol. Soc. Am. 94 818827.

Boore D M 2003 Simulation of ground motion using the stochastic method. In: Seismic motion, lithospheric structures, earthquake and volcanic sources: The Keiiti Aki volume, Birkhauser Basel, pp. 635-676.

Borok V K 1959 On estimation of the displacement in an earthquake source and of source dimensions; Ann. Geophys. 12 205-214. 
Bouchon M 1981 A simple method to calculate Green's functions for elastic layered media; Bull. Seismol. Soc. Am. 71 959-971.

Brune J N 1970 Tectonic stress and the spectra of seismic shear waves from earthquakes; J. Geophys. Res. 75 49975009 .

Chopra S, Yadav R B S, Patel H, Kumar S, Rao K M, Rastogi B K, Hameed A and Srivastava S 2008a The Gujarat (India) seismic network; Seismol. Res. Lett. 79 806815.

Chopra S, Rao K M, Sairam B, Kumar S, Gupta A K, Patel H, Gadhavi M S and Rastogi B K 2008b Earthquake swarm activities after rains in peninsular India and a case study from Jamnagar; J. Geol. Soc. India 72 245252.

Chung W-Y and Gao H 1995 Source parameters of the Anjar earthquake of July 21, 1956, India, and its seismotectonic implications for the Kutch rift basin; Tectonophys. 242 281-292.

Chung W-Y 1993 Source parameters of two riftassociated intraplate earthquakes in peninsular India: The Bhadrachalam earthquake of April 13, 1969 and the Broach earthquake of March 23, 1970; Tectonophys. 225 219-230.

Cohn S N, Hong T-L and Helmberger D V 1982 The Oroville earthquakes: A study of source characteristics and site effects; J. Geophys. Res. Solid Earth 87 4585-4594.

Coutant O 1989 Numerical study of the diffraction of elastic waves by fluid-filled cracks; J. Geophys. Res. Solid Earth 94 17805-17818.

Dimri V 1992 Deconvolution and inverse theory: Application to geophysical problems; Elsevier Science Publishers, Amsterdam, 230p.

Fletcher J, Boatwright J, Haar L, Hanks T and McGarr A 1984 Source parameters for aftershocks of the Oroville, California, earthquake; Bull. Seismol. Soc. Am. 74 11011123.

GSI 2001 Geology and mineral resources of Gujarat, Daman and Diu; Geological Survey of India (GSI).

Gupta H K, Harinarayana T, Kousalya M, Mishra D C, Mohan I, Rao N P, Raju P S, Rastogi B K, Reddy P R and Sarkar D 2001 Bhuj earthquake of 26 January, 2001; J. Geol. Soc. India 57 275-278.

Gupta H K 1985 The present status of reservoir induced seismicity investigations with special emphasis on Koyna earthquakes; Tectonophys. 118 257-279.

Hanks T C and Kanamori H 1979 A moment magnitude scale; J. Geophys. Res. Solid Earth 84 2348-2350.

Hanks T C 1977 Earthquake stress drops, ambient tectonic stresses and stresses that drive plate motions; Pure Appl. Geophys. 115 441-458.

Havskov J and Ottemoller L 1999 Seisan earthquake analysis software; Seismol. Res. Lett. 70 532-534.

Hazarika P and Kumar M R 2012 Seismicity and source parameters of moderate earthquakes in Sikkim Himalaya; Nat. Hazards 62 937-952.

Herrmann R B and Kijko A 1983 Modeling some empirical vertical component Lg relations; Bull. Seismol. Soc. Am. 73 157-171.

Herrmann R B 1985 An extension of random vibration theory estimates of strong ground motion to large distances; Bull. Seismol. Soc. Am. 75 1447-1453.
Huang Y, William L E and Gregory C B 2017 Stress drops of induced and tectonic earthquakes in the central United States are indistinguishable; Sci. Adv. 3(8) e1700772.

Kayal J R, Zhao D, Mishra O P, De R and Singh O P 2002 The 2001 Bhuj earthquake: Tomographic evidence for fluids at the hypocenter and its implications for rupture nucleation; Geophys. Res. Lett. 292152.

Kanamori H K and Anderson D L 1975 Theoretical basis of some empirical relations in seismology; Bull. Seismol. Soc. Am. 65 1073-1095.

Kikuchi M and Kanamori H 1991 Inversion of complex body waves-III; Bull. Seismol. Soc. Am. 81 2335-2350.

Kumar B A, Ramana D V, Kumar C P, Rani V S, Shekar M, Srinagesh D and Chadha R K 2006 Estimation of source parameters for 14 March 2005 earthquake of KoynaWarna region; Curr. Sci. 25 526-530.

Kumar S, Chopra S, Choudhury P, Singh A P, Yadav R B S and Rastogi B K 2012 Ambient noise levels in Gujarat State (India) seismic network; Geomat. Nat. Haz. Risk 3(4) 342-354.

Kumar M, Yallanki V S, Biswas K and Mandal P 2015 Evidence for non-self-similarity in the $\mathrm{Mw} 7.72001$ Bhuj earthquake sequence; Nat. Hazards 75 1577-1598.

Kumar S, Kumar D and Rastogi B K 2014 Source parameters and scaling relations for small earthquakes in the Kachchh region of Gujarat, India; Nat. Hazards 731269 1289 .

Langston C A and Helmberger D V 1975 A procedure for modelling shallow dislocation sources; Geophys. J. Int. 42 117-130.

Lee W H K, Kanamori H, Jennings P and Kisslinger C 2003 International handbook of earthquake $\mathcal{G}$ engineering seismology; Academic Press, New York.

Mandal P and Dutta U 2011 Estimation of earthquake source parameters in the Kachchh seismic zone, Gujarat, India, from strong-motion network data using a generalized inversion technique; Bull. Seismol. Soc. Am. 101 1719-1731.

Mandal P and Johnston A 2006 Estimation of source parameters for the aftershocks of the $2001 \mathrm{Mw} 7.7$ Bhuj Earthquake, India; Pure Appl. Geophys. 163 1537-1560.

Mandal P, Joshi S, Kumar S, Bhunia R and Rastogi B K 2004a Low Coda Q c in the epicentral region of the 2001 Bhuj Earthquake of Mw 7.7; Pure Appl. Geophys. 161 1635-1654.

Mandal P, Narsaiah R, Sairam B, Satyamurty C and Raju I P 2006 Relocation of early and late aftershocks of the 2001 Bhuj Earthquake using Joint Hypocentral Determination (JHD) technique: Implication toward the continued aftershock activity for more than 4 years; Pure Appl. Geophys. 163 1561-1581.

Mandal P and Pujol J 2006 Seismic imaging of the aftershock zone of the $2001 \mathrm{M}_{\mathrm{w}} 7.7$ Bhuj earthquake, India; Geophys. Res. Lett. 33 L05309, https://doi.org/10.1029/ 2005GL025275.

Mandal P, Rastogi B K and Sarma C S P 1998 Source parameters of Koyna earthquakes, India; Bull. Seismol. Soc. Am. 88 833-842.

Mandal P, Rastogi B K, Satyanarayana H V S and Kousalya M 2004b Results from local earthquake velocity tomography: Implications toward the source process involved in generating the 2001 Bhuj Earthquake in the lower crust 
beneath Kachchh (India); Bull. Seismol. Soc. Am. 94 633-649.

Mandal P, Satyamurty C and Raju I P 2009 Iterative deconvolution of the local waveforms: Characterization of the seismic sources in Kachchh, India; Tectonophys. 478 $143-157$.

Mandal P 2008 Stress rotation in the Kachchh rift zone, Gujarat, India; Pure Appl. Geophys. 165 1307-1324.

Mandal P, Chadha R K, Raju I P, Kumar N, Satyamurty C, Narsaiah R and Maji A 2007 Coulomb static stress variations in the Kachchh, Gujarat, India: Implications for the occurrences of two recent earthquakes $\left(\mathrm{M}_{\mathrm{w}}=5.6\right)$ in the 2001 Bhuj earthjquake region; Geophys. J. Int. 169 281-285.

Merh S S 1995 Geology of Gujarat; GSI Publ., Kolkata 2(1).

Mishra O P and Zhao D 2003 Crack density, saturation rate and porosity at the 2001 Bhuj, India, earthquake hypocenter: A fluid-driven earthquake; Earth Planet Sci. Lett. 21 393-405.

Nagamani D and Mandal P 2017 Estimation of earthquake source parameters in the Kachchh seismic zone, Gujarat, India, using three component S-wave spectra; J. Asian Earth Sci. 126(6) 74.

Naganjaneyulu K, Ledo J J and Queralt P 2010 Deep crustal electromagnetic structure of Bhuj earthquake region (India) and its implications; Geol. Acta 8 83-97.

Negishi H, Mori J, Sato T, Singh R, Kumar S and Hirata N 2002 Size and orientation of the fault plane for the 2001 Gujarat, India earthquake (Mw 7.7) from aftershock observations: A high stress drop event; Geophys. Res. Lett. 291949.

Paul D K, Potts P J, Rex D C and Beckinsale R D 1977 Geochemical and petrogenetic study of the Girnar igneous complex, Deccan volcanic province, India; Geol. Soc. Am. Bull. 88 227-234.

Peterson J R 1993 Observations and modeling of seismic background noise; Report No. 93-322, Geological Survey (US).

Rapolu N and Mandal P 2014 Source parameters of the $2001 \mathrm{Mw} 7.7$ Bhuj earthquake, Gujarat, India, aftershock sequence; J. Geol. Soc. India 83 517-531.

Rajendran C P and Rajendran K 2001 Characteristics of deformation and past seismicity associated with the 1819 Kutch Earthquake, northwestern India; Bull. Seismol. Soc. Am. 91 407-426.

Rajendran K and Rajendran C P 1999 Seismogenesis in the stable continental interiors: An appraisal based on two examples from India; Tectonophys. 305 355-370.

Ramasamy S M 1995 Deformation tectonics of Deccan volcanics of southern Saurashtra lndia and its relation to western extension of Narmada lineament; In: Magmatism in relation to diverse tectonism settings (eds) Srivastava R K and Chandra R, Oxford and IBH Publ. Co., New Delhi, pp. 195-208.

Rao B R and Rao P S 1984 Historical seismicity of peninsular India; Bull. Seismol. Soc. Am. 74 2519-2533.

Rao C N, Rao N P and Rastogi B K 2013 Evidence for right-lateral strike-slip environment in the Kutch basin of northwestern India from moment tensor inversion studies; J. Asian Earth Sci. 64 158-167.

Rastogi B K, Mandal P and Biswas S K 2014 Seismogenesis of earthquakes occurring in the ancient rift basin of Kachchh, western India; In: Intraplate earthquakes, Cambridge University Press, New York, pp. 126-161.

Saha A, Lijesh S and Mandal P 2012 Simultaneous estimation of earthquake source parameters and crustal $Q$ value from broadband data of selected aftershocks of the 2001 Mw 7.7 Bhuj earthquake; J. Asian Earth Sci. 121 14211440 .

Sairam B 2012 Study of source parameters and seismotectonics of the Gujarat State: Implications towards the seismic risk mitigation; Hyderabad: Osmania University.

Sastry R S, Nandini N and Sarma S V S 2008 Electrical imaging of deep crustal features of Kutch, India. Geophys. J. Int. 172 934-944.

Sheth H C, Choudhary A K, Cucciniello C, Bhattacharyya S, Laishram R and Gurav T 2012 Geology, petrochemistry, and genesis of the bimodal lavas of Osham Hill, Saurashtra, northwestern Deccan Traps; J. Asian Earth Sci. 43 176-192.

Singh S K, Bansal B K, Bhattacharya S N, Pacheco J F, Dattatrayam R S, Ordaz M, Suresh G, Kamal and Hough S E 2003 Estimation of ground motion for Bhuj (26 January 2001; Mw 7.6) and for future earthquakes in India; Bull. Seismol. Soc. Am. 93 353-370.

Singh A P, Kumar M R, Kumar S, Sateesh A, Mahesh P, Shukla A and Talukdar R 2017 Seismicity and subterranean sounds in the northwest Deccan volcanic province of India; Bull. Seismol. Soc. Am. 107(3) 1129-1135.

Singh A P, Mishra O P, Rastogi B K and Kumar S 2013 Crustal heterogeneities beneath the 2011 Talala, Saurashtra earthquake, Gujarat, India source zone: Seismological evidence for neo-tectonics; J. Asian Earth Sci. 62672 684.

Singh A P, Mishra O P, Yadav R B S and Kumar D 2012 A new insight into crustal heterogeneity beneath the 2001 Bhuj earthquake region of northwest India and its implications for rupture initiations; J. Asian Earth Sci. 48 31-42.

Singh A P and Mishra O P 2015 Seismological evidence for monsoon induced micro to moderate earthquake sequence beneath the 2011 Talala, Saurashtra earthquake, Gujarat, India; Tectonophys. 661 38-48.

Singh A P, Roy I G, Kumar S and Kayal J R 2015 Seismic source characteristics in Kachchh and Saurashtra regions of western India: B-value and fractal dimension mapping of aftershock sequences; Nat. Hazards 77 33-49.

Singh A P, Zhao L, Kumar S and Mishra S 2016 Inversions for earthquake focal mechanisms and regional stress in the Kachchh Rift Basin, western India: Tectonic implications; J. Asian Earth Sci. 117 269-283.

Singh S K, Apsel R J, Fried J and Brune J N 1982 Spectral attenuation of $\mathrm{SH}$ waves along the imperial fault; Bull. Seismol. Soc. Am. 72 2003-2016.

Singh S K, Pacheco J F, Bansal B K, Perez-Campos X, Dattatrayam R S and Suresh G 2004 A Source study of the Bhuj, India, earthquake of 26 January 2001 (Mw 7.6); Bull. Seismol. Soc. Am. 94 1195-1206.

Sivaram K, Kumar D, Teotia S S, Rai S S and Prakam K S 2013 Source parameters-scaling relations for small earthquakes in Kumaon Himalaya India; J. Seismol. 17 579-592.

Sokos E N and Zahradnik J 2008 ISOLA a Fortran code and a Matlab GUI to perform multiple-point source inversion of seismic data; Comput. Geosci. 34 967-977. 
Srivastava S and Rao D T 1997 Present status of seismicity of Gujarat, Vayu Mandal Jan-Jun 27 32-39.

Talwani P and Gangopadhyay A 2001 Tectonic framework of the Kachchh Earthquake of 26 January 2001; Seismol. Res. Lett. 72 336-345.

Trivedi P C and Parvez I A 2015 Characterization of source parameters and some empirical relations between them for Kachchh Region, Gujarat, India: Implication of January 26, 2001 Bhuj Earthquake and its aftershock sequence; Int. J. Geosci. 6 1127-1139.

Yadav R B S, Papadimitriou E E, Karakostas V G, Shanker D, Rastogi B K, Chopra S, Singh A P and Kumar S 2011
The 2007 Talala, Saurashtra, western India earthquake sequence: Tectonic implications and seismicity triggering; J. Asian Earth Sci. 40 303-314.

Yadav A, Shashidhar D, Mallika K, Rao N P, Rohilla S, Satyanarayana H V S, Srinagesh D and Gupta H 2013 Source parameters of earthquakes in the reservoirtriggered seismic (RTS) zone of Koyna-Warna, western India; Nat. Hazards 69 965-979.

Zahradnik J, Serpetsidaki A, Sokos E and Tselentis G A 2005 Iterative deconvolution of regional waveforms and a double-event interpretation of the 2003 Lefkada Earthquake; Greece Bull. Seismol. Soc. Am. 95 159-172.

Corresponding editor: N V CHALAPATHI RAO 